\title{
300 Million years of episodic hydrothermal activity: stable isotope evidence from hydrothermal rocks of the Eastern Iberian Central System
}

\begin{abstract}
The Eastern Iberian Central System has abundant ore showings hosted by a wide variety of hydrothermal rocks; they include $\mathrm{Sn}-\mathrm{W}, \mathrm{Fe}$ and $\mathrm{Zn}-(\mathrm{W})$ calcic and magnesian skarns, shear zone- and episyenitehosted $\mathrm{Cu}-\mathrm{Zn}-\mathrm{Sn}-\mathrm{W}$ orebodies, $\mathrm{Cu}-\mathrm{W}-\mathrm{Sn}$ greisens and $\mathrm{W}-(\mathrm{Sn})$, base metal and fluorite-barite veins. Systematic dating and fluid inclusion studies show that they can be grouped into several hydrothermal episodes related with the waning Variscan orogeny. The first event was at about $295 \mathrm{Ma}$ followed by younger pulses associated with Early Alpine rifting and extension and dated near 277,150 and 100 to $20 \mathrm{Ma}$, respectively (events II IV). The $\delta^{18} \mathrm{O}-\delta \mathrm{D}$ and $\delta^{34} \mathrm{~S}$ studies of hydrothermal rocks have elucidated the hydrological evolution of these systems. The event I fluids are of mixed origin. They are metamorphic fluids $\left(\mathrm{H}_{2} \mathrm{O}-\mathrm{CO}_{2}-\mathrm{CH}_{4}-\mathrm{NaCl} ; \delta^{18} \mathrm{O}=4.7\right.$ to $9.3 \% ; \delta \mathrm{D}$ ab. $-34 \%$ ) related to $\mathrm{W}-(\mathrm{Sn})$ veins and modified meteoric waters in the deep magnesian Sn-W skarns $\left(\mathrm{H}_{2} \mathrm{O}-\mathrm{NaCl}, 4.56 .4 \mathrm{wt} \% \mathrm{NaCl}\right.$ eq.; $\delta^{18} \mathrm{O}=7.3$ $7.8 \% ; \delta \mathrm{D}=-77$ to $-74 \%$ ) and epizonal shallow calcic $\mathrm{Zn}-(\mathrm{W})$ and $\mathrm{Fe}$ skarns $\left(\mathrm{H}_{2} \mathrm{O}-\mathrm{NaCl},<8 \mathrm{wt} \% \mathrm{NaCl}\right.$ eq.; $\delta^{18} \mathrm{O}=-0.4$ to $3.4 \% ; \delta \mathrm{D}=-75$ to $-58 \%$. . They were probably formed by local hydrothermal cells that were spatially and temporally related to the youngest Variscan granites, the metals precipitating by fluid unmixing and fluid-rock reactions. The minor influence of magmatic fluids confirms that the intrusion of these granites was essentially water-undersaturated, as most of the
\end{abstract}

hydrothermal fluids were external to the igneous rocks. The fluids involved in the younger hydrothermal systems (events II III) are very similar. The waters involved in the formation of episyenites, chlorite-rich greisens, retrograde skarns and phyllic and chlorite-rich alterations in the shear zones show no major chemical or isotopic differences. Interaction of the hydrothermal fluids with the host rocks was the main mechanism of ore formation. The composition $\left(\mathrm{H}_{2} \mathrm{O}-\mathrm{NaCl}\right.$ fluids with original salinities below $6.2 \mathrm{wt} \% \mathrm{NaCl}$ eq.) and the $\delta^{18} \mathrm{O}$ $(-4.6$ to $6.3 \%)$ and $\delta \mathrm{D}(-51$ to $-40 \%)$ values are consistent with a meteoric origin, with a $\delta^{18} \mathrm{O}$-shift caused by the interaction with the, mostly igneous, host rocks. These fluids circulated within regional-scale convective cells and were then channelled along major crustal discontinuities. In these shear zones the more easily altered minerals such as feldspars, actinolite and chlorite had their $\delta^{18} \mathrm{O}$ signatures overprinted by low temperature younger events while the quartz inherited the original signature. In the shallower portions of the hydrothermal systems, basement-cover fluorite-barite-base metal veins formed by mixing of these deep fluids with downwards percolating brines. These brines are also interpreted as of meteoric origin $\left(\delta^{18} \mathrm{O}<\approx-4 \% ; \delta \mathrm{D}=-65\right.$ to $-36 \%$. that leached the solutes (salinity $>14$ wt $\% \mathrm{NaCl}$ eq.) from evaporites hosted in the post-Variscan sequence. The $\delta \mathrm{D}$ values are very similar to most of those recorded by Kelly and Rye in Panasqueira and confirm that the Upper Paleozoic meteoric waters in central Iberia had very negative $\delta \mathrm{D}$ values $(\leq-52 \%$ ) whereas those of Early Mesozoic age ranged between -65 and $-36 \%$.

\section{Introduction}

The circulation of hydrothermal fluids through the upper crust is a common geological process that leads to the pervasive retrograde alteration of metamorphic and igneous rocks as well as to the formation of ore deposits and geothermal systems. In the Variscan Belt of Europe, such hydrothermal alteration and related mineralization 
typically are associated to Variscan granitoids (e.g., Jackson et al. 1982; Turpin et al. 1990). Until recently, many of these hydrothermal rocks were interpreted as directly linked to the waning stages of plutonism. However, systematic geochronological, isotopic and fluid inclusion studies have shown that most of the hydrothermal circulation is independent of the igneous activity and is related to large hydrothermal cells generated during younger tectonic processes (e.g., Bonhomme et al. 1987; Bril et al. 1991; Caballero et al. 1992; Dill and Nielsen 1987).

A remarkable case of complex and repeated hydrothermal activity is recorded in the Eastern Iberian Central System (EICS), where a wide range of hydrothermal rocks has been recognized (Fig. 1 and Table 1). Several tens of small mines and prospects are scattered in the area. They mined a wide range of orebodies including veins (W, $\mathrm{Sn}, \mathrm{As}, \mathrm{Cu}, \mathrm{Zn}, \mathrm{Pb}, \mathrm{Ag}$, fluorite, barite), skarns $(\mathrm{Cu}, \mathrm{Zn}, \mathrm{Sn}, \mathrm{Fe})$, episyenites $(\mathrm{Cu}, \mathrm{Zn}, \mathrm{Sn}, \mathrm{W})$ and greisens $(\mathrm{W}, \mathrm{Cu})$. The most remarkable deposits are the

Fig. 1 Simplified geological map of the Eastern Iberian Cent ral System with the locations described in the text
barite-Ag veins of the Hiendelaencina area, which was a leading silver producing district in the late XIX century (Martínez Frías 1992), and the Ahnadenes skarn with about $2.66 \mathrm{Mt}$ with $0.92 \% \mathrm{Cu}, 1.89 \% \mathrm{Zn}, \mathbf{0 . 2 4 \%} \mathrm{Sn}$, $0.13 \% \quad \mathrm{WO}_{3}$ and $38 \mathrm{~g} / \mathrm{t} \mathrm{Ag}$ (Tornos 1990). The abundance of igneous rocks of Variscan age in the area classically led to models in which the hydrothermal activity was related to the intrusion of granitoids and extrusion of andesites (e.g., Vindel 1980; Mayor et al. 1989; Martínez Frias 1992), associated with the extensional collapse of the orogen from 310 to $285 \mathrm{Ma}$ (Concha et al. 1992; Doblas et al. 1994; Lillo et al. 1992). However, recent geochronological and structural work has demonstrated that most hydrothermal alteration is younger than the granitic magmatism and that it occurred episodically from ca. 300 to, at least, $100 \mathrm{Ma}$, after regional neoformation and/or reactivation of fractures (e.g., Locutura and Tornos 1985; Caballero et al. 1992; Galindo et al. 1994b; González Casado et al. 1996).

The aim of this work is to trace the isotope composition of fluids and sulphur through the several episodes of hydrothermal activity recorded in the EICS. New isotope determinations on minerals and fluid inclusions have been combined with earlier fluid inclusion and

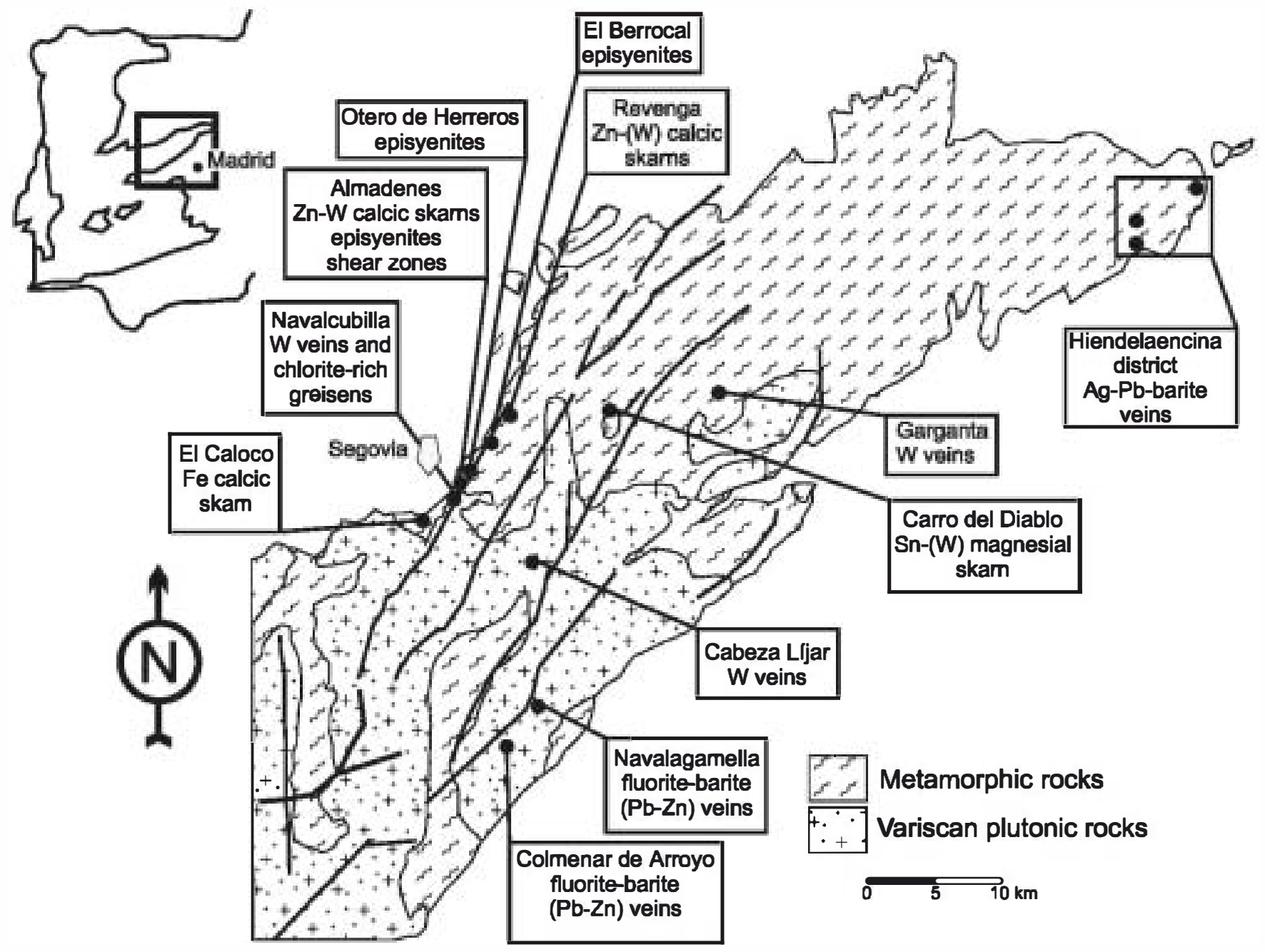


Table 1 Sequence and main characteristics of hydrothermal events in the Eastern Iberian Central System

\begin{tabular}{lll}
\hline Event Hydrothermal rocks $\quad$ Age $\quad$ Geologic setting & $\begin{array}{l}\text { P-T conditions and fluid References } \\
\text { composition }\end{array}$
\end{tabular}

\section{W-(Sn) quartz veins and related early greisens}

Early Fe calcic skarns Sn-W magnesian proximal
skarns

$\mathrm{Zn}-(\mathrm{W})$ calcic distal skarns ??

II Episyenites

Scheelite and sulphide-rich veins and chlorite- and cassiterite-, scheelite- and sulphide-bearing greisens

Late Fe calcic skarns

III

Acid alteration (silicification $155 \pm 7$ and sericitization) and synchronous late skarn close to shear bands

\section{Chloritites}

Fluorite-barite $(\mathrm{Pb}-\mathrm{Zn}-\mathrm{Ag})$ basement-cover veins

IV Late quartz veins and silica replacements
$284 \pm 3$

\section{$295 \pm 10$ Usually in minor extensional} fractures located in the endoand exocontact of shallow and small granitic plutons. Locally in regional stuctures

$296 \pm 3$ ? Pyroxene-garnet skarn in metabasites, gabbros, calcsilicate rocks and skarnoids near E-W porphyry dikes. Superimposed on a $\mathbf{D}_{2}$ Variscan shear zone

On dolomitic marbles located near leucogranites in the roof of mesozonal granodioritic plutons. No significant structural control

$? ?$

Hedenbergite-rich skarn in dolomitic marbles interbedded with gneisses and near aplitic dykes. No major structural control. Distal to epizonal granites?

$274 \pm 6 \quad$ Kilomere-sized extensional bands of WNW-ESE trend mostly in granitoids. Unknown relationship with synchronous igneous rocks

$267 \pm 7$ Reactivation of earlier W-Sn quartz veins with alteration of their selvage along WNW-ESE structures

$259 \pm 7$ Amphibole-magnetite skarn on earlier skarn, metabasites, calcsilicate rocks and skarnoids

Quartz, sericite and chlorite-rich rocks in mylonitized granitoids and episyenites in WNW ESE structures. Amphibolitic and epidotitic skarns in marbles and calcic distal skarns

$165 \pm 5$ Chlorite and quartz-rich rocks in the more altered tectonites in WNW ESE structures postdating the acid alteration

$145 \pm 18$ Extensional and brittle vertical faults with WNW ESE and ENE WSW trend

$101 \pm 4$ Strike-slip and extensional and NNW SSE vertical faults and younger silica-rich replacements in marbles (?)

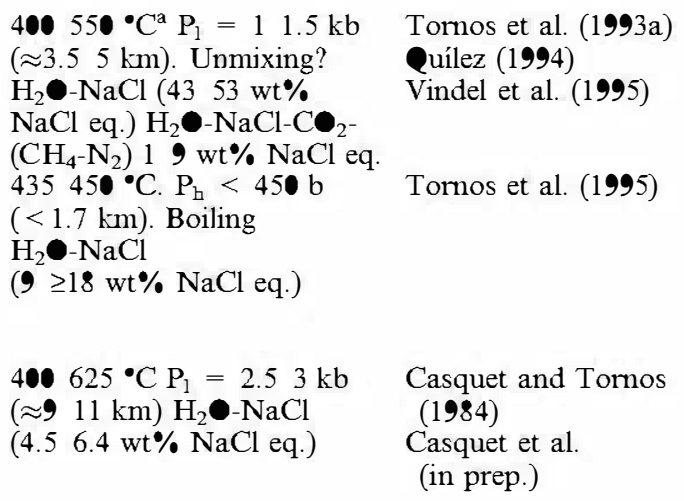

Casquet and Tornos (1984) Casquet et al. (in prep.)

Tornos (1990)

$250380^{\circ} \mathrm{C} \mathrm{P}_{\mathrm{h}} \approx \mathrm{L}-\mathrm{V}$ ( $<3 \mathrm{~km}$ ). Boiling $\mathrm{H}_{2}$ - $\mathrm{NaCl}-$

$\mathrm{KCl}-\left(\mathrm{CaCl}_{2}-\mathrm{MgCl}_{2}\right)$

( $11.5 \mathrm{wt} \% \mathrm{NaCl}$ eq.) ab. $400^{\circ} \mathrm{C}$

Tornos et al. (1995)

$285420^{\circ} \mathrm{C} \mathrm{P}_{\mathrm{h}} \approx \mathrm{L}-\mathrm{V}$.

Boiling $\mathrm{H}_{2}-\mathrm{NaCl}$

Tornos (1990)

( .24 .5 wt $\% \mathrm{NaCl}$ eq.)

$242340^{\circ} \mathrm{C} \mathrm{P}_{\mathrm{h}} \approx \mathrm{L}-\mathrm{V}$

Boiling $\mathrm{H}_{2}-\mathrm{NaCl}$

(-2 4.5 wt $\% \mathrm{NaCl}$ eq.)

Tornos (1990)

$\approx 120270^{\circ} \mathrm{C} \mathrm{P}_{\mathrm{h}} \approx \mathrm{L}-\mathrm{V}$.

Tornos et al. (1993a)

Fluid mixing:

I: $\mathrm{H}_{2}-\mathrm{NaCl}-\mathrm{KCl}$

( $<3.4 \mathrm{wt} \% \mathrm{NaCl}$ eq.)

II: $\mathrm{H}_{2}-\mathrm{CaCl}_{2}-\mathrm{MgCl}_{2}-\mathrm{KCl}$ -

$\mathrm{NaCl}(>14 \mathrm{wt} \% \mathrm{NaCl}$ eq.)

No data (assumed $180^{\circ} \mathrm{C}$ )

Caballero et al. (1992) Galindo et al. (1994b)

$\overline{{ }^{a}}$ Estimated from fluid inclusion data of Quílez (1994) for a fluid pressure close to $11.5 \mathrm{~kb}$, the minimum pressure of in associated granites

radiogenic isotope data. Despite the importance of Sn$\mathrm{W}, \mathrm{Zn}-\mathrm{Pb}, \mathrm{Au}$ and other mineralization in the western Iberian Peninsula, stable isotope $\delta^{18} \mathrm{O}-\delta \mathrm{D}$ studies are scarce. Besides the comprehensive work of Kelly and Rye (1979) at Panasqueira (Portugal), we also quote here the works of Concha et al. (1992), Lillo et al. (1992), Caballero (1993), Antona et al. (1994), Galindo et al. (1994b), Mangas and Pérez Torrado (1995),
Tornos et al. (1996) and Reyes et al. (1998), which are of relevance to the present study.

\section{Geological setting}

The Iberian Central System consists of elongated blocks of Variscan basement that underwent strong uplift in the 
Cenozoic displaying a pop-up geometry and a ENE WSW trend. Granitoids and low- to high-grade metamorphic rocks are the most abundant rocks in this basement, which is unconformably covered by Upper Carboniferous to Tertiary sedimentary rocks (Fig. 1). Important tectonic activity along master faults is recorded at different ages and persists to the present. Metamorphic rocks include abundant pre-Variscan peraluminous orthogneisses of Lower Ordovician age (Vialette et al. 1987) and detrital and carbonate rocks of Precambrian Devonian age. High- and medium-grade metamorphic rocks and granitoids occupy the lower plate of a large extensional structure developed during the late-Variscan extensional collapse of the orogen (Casquet et al. 1988; Doblas 1987). Most of the hydrothermal rocks dealt with here are hosted by high-grade metamorphic rocks and granitoids.

Intrusion of the granite batholith took place between 345 and $285 \mathrm{Ma}$, at pressures of $23 \mathrm{~kb}$, encompassing the late extensional collapse of the orogen in the Carboniferous and a subsequent phase of regional wrench faulting during the Lower Permian (Gonzalez-Casado et al. 1996). The granitoids are weakly to strongly peraluminous, biotite ( \pm cordierite) monzogranites, biotite granites and biotite ( \pm muscovite) leucogranites. Ihnenite and pyrrhotite are common accessory minerals (for a review see Villaseca et al. 1993 and references therein). A remarkable feature is the occurrence of long (up to $50 \mathrm{~km}$ ), roughly parallel, E W trending (few trending N S) discordant dyke swarms consisting of granite porphyries and minor microdiorites. Local small and epizonal (probably $11.5 \mathrm{~kb}$ ) fine-grained to microporphyritic granitic cupolas seem to be related to shallow dyke ends (Tornos et al. 1993a). The age of one $\mathrm{E} \mathrm{W}$ dyke is $296 \pm 3 \mathrm{Ma}$. A younger set of a few dykes of alkaline affinity has been dated at $245 \pm 7 \mathrm{Ma}(\mathrm{K} /$ Ar; Galindo et al. 1994a).

\section{Review of the hydrothennal activity in the eastern ECS}

Hydrothermal rocks are abundant and have con asing characteristics. The geochemical, mineralogical and structural similarities (e.g., Locutura and Tornos 1985; González Casado et al. 1996) as well as the age of formation (Caballero et al. 1992; Galindo et al. $1994 \mathrm{~b}$ ) allow them to be related to four major hydrothermal events that were the result of major tectonism between 300 and $100 \mathrm{Ma}$ (Table 1). The main characteristics of these hydrothermal events are shown in Table 1. It is noteworthy that the radiometric ages are internally consistent and validated by the distinctive hydrothermal assemblages and crosscutting field relationships. Resetting seems to be of minor importance and only seems to occur in the episyenites because of overprinting by younger events (see below)

Event I (300 290 Ma; Upper Carboniferous)

Hydrothermal activity that can be unambiguously related to the huge granitic magmatism is scarce, probably because of fast unroofing of the batholith soon after emplacement. The earlier hydrothermal rocks are located in the immediate vicinity of the young granites and leucogranites, and occur as isolated small plutons or apical facies of major intrusions. Close to the deeper intrusions $(\approx 2.53 \mathrm{~kb})$ the fluid pressure seems unable to form dilatational zones and hydrothermal rocks are restricted to minor skarns where metals precipitated by reaction of the hydrothermal fluids with dolomitic and calcitic marbles. This is the case of the magnesian Sn-W Carro del Diablo skarn (Fig. 2a; Casquet and Tornos 1984; Casquet et al., in preparation), formed by the replacement of marbles near the contact with a circa $302 \mathrm{Ma}$ biotite granite stock. Minor scheelite-bearing $\mathrm{Ca}$-skarns and skarnoids found away from the contact in the Carro del Diablo area probably formed at the same time.

A second group of hydrothermal rocks is represented by the $\mathrm{W}$-(Sn)-bearing quartz veins and fracture-controlled greisens (Quílez et al. 1990; Quílez 1994; Vindel et al. 1995) that have provided K-Ar mineral ages between $302 \pm 6$ and $291 \pm 8 \mathrm{Ma}$ (Caballero et al. 1992). These rocks formed, during the phase of strike-slip faulting, soon after the extensional collapse of the Variscan orogen (Gonzalez Casado et al. 1993, 1996). They are commonly found in relationship with the apical zones of epizonal leucogranites, sometimes microporphyritic (Tornos et al. 1993a).

Distal $\mathrm{Zn}$-(W) calcic skarns also occur on marbles away from the granites but always spatially related to minor aplitic dykes. Their age is unknown but all these skarns are interpreted by Tornos (1990) as related to hydrothermal convective cells driven by the granitic in rusions. Finally, there are some shallow iron-rich calcic skarns that display a simple zonal arrangement with an early event in which garnet, pyroxene and idocrase replaced calc-silicate rocks, old syn-metamorphic skarns, metabasites and gabbros (Tornos et al. 1995). They replace the $\mathrm{E} W$ dykes dated at $296 \pm 3 \mathrm{Ma}$ and can be tentatively assigned to this event I because the superimposed retrograde alteration is dated as related with event II.

Fluids involved in this event are diverse. They include low saline waters in the $\mathrm{Sn}-\mathrm{W}$ and $\mathrm{Zn}$-(W) skarns (4.5 6.4 and $8 \mathrm{wt} \% \mathrm{NaCl}$ eq., respectively), more saline boiling solutions ( $>9 \mathrm{wt} \% \mathrm{NaCl}$ eq.) in the Fe-rich skarn and complex $\mathrm{H}_{2}-\mathrm{CO}_{2}-\mathrm{CH}_{4}-\mathrm{NaCl}$ fluids in the $\mathrm{W}$-(Sn)-bearing veins (Tables 1 and 2). These W-(Sn) quartz veins often record complex hydrothermal histories involving a diversity of fluid sources and episodic processes of mixing and unmixing of fluids, which was probably the dominant mechanism of ore precipitaion (e.g., Quílez 1994; Vindel et al. 1995), similarly as in other W-Sn veins of the Variscan Belt (e.g., Noronha 1984; Ramboz et al. 1985; Mangas and Arribas 1987)

\section{Event II (circa $277 \mathrm{Ma}$; Permian)}

The age of this stage has been determined from the weighted mean of several $\mathrm{Rb}$-Sr internal isochron ages obtained on episyenites (Caballero et al. 1993). Episyenites are hydrothermal metasomatic rocks that consist in most cases of albite-rich plagioclase and a combination of mafic minerals: hedenbergite to aegirinic augite pyroxene, hastingsite amphibole, biotite, epidote and chlorite (Fig. 2b). These rocks are common in the EICS; they replace the granites and dykes and occur largely as subvertical lens-shaped bodies with trends close to $\mathrm{N} 11^{\circ} \mathrm{E}$ and NNE SSE. The episyenites result from the dequartrification and alkali metasomatism of the granites along microfractured extensional bands. Numerical calculations show that these rocks formed in relationship with a drop in the fluid pressure from lithostatic to almost hydrostatic values. Changes in the fluid composition led to a $\mathrm{pH}$ increase, dissolution of quartz and precipitation of feldspars (Casquet et al. 1992b). Fluids involved were low to moderately saline $\left(\mathrm{H}_{2}-\mathrm{NaCl}\right.$; $<12 \mathrm{wt} \% \mathrm{NaCl}$ eq.) with temperatures between 350 and $620^{\circ} \mathrm{C}$ and recorded fluid pressures of 1.5 to $1.7 \mathrm{~kb}$. The episyenites are related to the development of an important regional thermal anomaly resulting from an extensional event directly related with the onset of the Alpine cycle, and the beginning of rifting leading to the opening of the Iberian trough (Caballero et al. 1992; González Casado et al. 1996)

Reactivation of the episyenitic bands during younger hydrothermal events is shown by the common presence of chlorite-rich rocks (chloritites) in the core of the episyenitic bands and the partial resetting of the K-Ar mineral ages (between $265 \pm 4$ and $216 \pm 4 \mathrm{Ma}$; Caballero et al. 1992). 

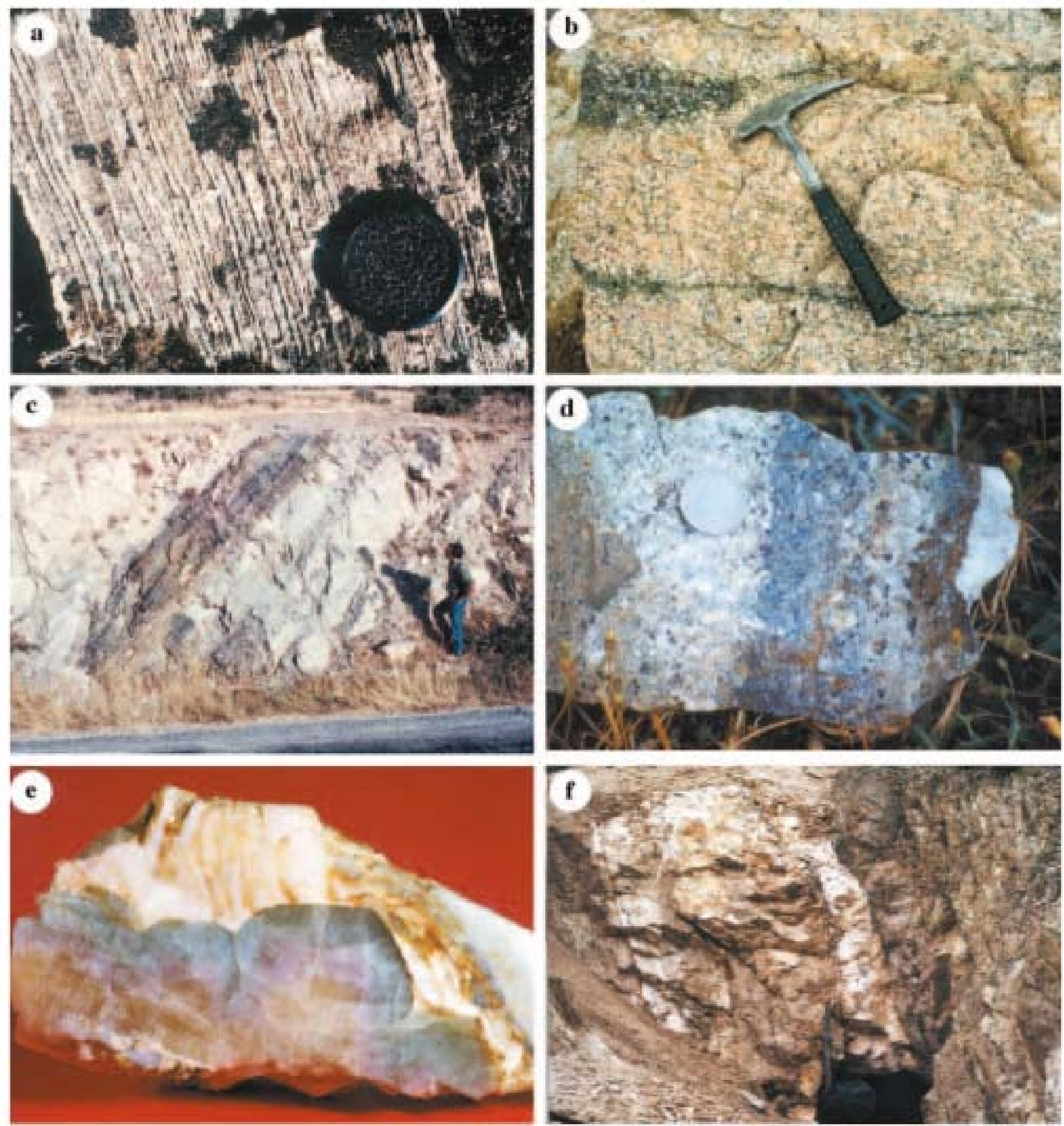

Fig. 2 Typical hydrothermal rocks of the Eastorn Iberian Central System. a Sn-W laminar magnesian skam of El Carro del Diablo, rdatod to the event $I$. The veins are composod of diopside, chondredite and phogopite, whereas the intorstitial material up mainly of calcite, flubboite and chendredite; b episyenite formed. aleng major WNW-ESE structures during event II, replaced. by chositic alteration related. to the event III. Otero de Herreros. c Extensional shear zone associalod with phlyllic alteration event III. Otero de Herreros. d l.ow-temperature, chlorite- and sulphide-jich

greisen formed dwing the event $I$ synchronously with the replacement of wolframite by suphides in the W-Sn veins. Navalcubilla. e Zonation in the fluorite-basite-sich veins with fluorite at the margin and barite in the core of the veins. Colmenar de Arroyo. There is a progressive increase in salinity and drop in homegenization temperatures duing the precipitation minerals $f$ Darite vein related to the shallow zores of event $\Pi I$ hydrothermal systems. With depth these veins change abruptly to fuerite-sich veins. Navalagamella. 
Table 2 Gas composition for the different hydrothermal fluids. n.d. Not detected

\begin{tabular}{|c|c|c|c|c|c|c|c|}
\hline & $\mathrm{XH}_{2}$ & $\mathrm{XCO}_{2}$ & $\mathrm{XCH}_{4}$ & $\mathrm{XN}_{2}$ & $\mathrm{XH}_{2}$ & $\mathrm{XCO}$ & References \\
\hline Distal calcic skarn $(n=2)$ & 98.20 & 1.04 & 0.06 & n.d. & 0.45 & 0.25 & This work ${ }^{\mathrm{a}}$ \\
\hline Episyenites & $100 ?$ & n.d. & n.d. & n.d. & n.d. & n.d. & This work ${ }^{b}$ \\
\hline $\begin{array}{l}\text { Sulphide-rich veins and chlorite and } \\
\text { sulphide-rich greisen }(n=2)\end{array}$ & 97.75 & 1.42 & $\bullet .15$ & n.d. & - 24 & 0.46 & Tornos et al. $(1993 a)^{a}$ \\
\hline Acid alteration and chloritites & $100 ?$ & n.d. & n.d. & n.d. & n.d. & n.d. & This work $^{a}$ \\
\hline
\end{tabular}

${ }^{a}$ Mass spectrometry of bulk samples (BGS, Keyworth, in collaboration with T.J. Shepherd)

${ }^{b}$ RAMAN (CREGU, Nancy) analysis performed by E. Quílez

Probably synchronous $(267 \pm 7 \mathrm{Ma} ; \mathrm{K}$-Ar age on muscovite) within the errors of the ages of episyenite formation, boiling lowsalinity water-rich fluids circulated through reactivated $\mathrm{W}$-quartz veins, leading to the widespread precipitation of scheelite, arsenopyrite, cassiterite and base metal sulphides (sphalerite, galena, bismuthinite, stannite). In the selvage of the veins, low-temperature cassiterite-scheelite-sulphide-bearing chlorite-rich greisens also formed (Fig. 2c; Tornos et al. 1993a).

The low-temperature alteration of the calcic Fe-rich skarn produced magnetite and $\mathrm{Cl}$-rich amphiboles (hasingsite and pargasite). A K-Ar determination of one amphibole gave an age of $259 \pm 7 \mathrm{Ma}$.

Event III (ca. $150 \mathrm{Ma}$; Upper Jurassic)

During this event, part of the older fractures were reactivated as strike-slip or normal faults with the generation of metre sized bodies of ultracataclasites (Fig. 2d). A pervasive phyllic alteration (quartz + phengite \pm chlorite) took place near the fractures. Subsequently, it was replaced by massive chloritites (chlorite + quartz \pm phengite \pm ahnandine \pm epidote \pm fluorite), located near the centre of the shear zones. This type of hydrothermal alteration is particularly strong wherever the faults crosscut rocks such as episyenites, marbles or anhydrous skarns (Tornos 1990). The latter are replaced by actinolite and epidote-rich retrograde skarns. Locally, huge hydrothermal breccias developed. All these rocks host a wide variety of ore minerals including magnetite, sphalerite, chalcopyrite, cassiterite, scheelite and $\mathrm{Bi}-\mathrm{Ag}-\mathrm{Cu}-\mathrm{Pb}$ sulphosalts. This hydrothermal alteration took place at temperatures of $250350 \mathrm{EC}$ and fluid pressures close to the LV curve, boiling being rather common. The fluids are similar to those associated with event II, but the salinities are somewhat lower $(\mathbf{0 . 2}$ $4.5 \mathrm{wt} \% \mathrm{NaCl}$ eq.).

$\mathrm{K}-\mathrm{Ar}$ dating of sericites at different localities has provided fairly uniform ages close to $150 \mathrm{Ma}$ (Caballero et al. 1992). This hydrothermal event has been related to the opening of the North Atlantic Ocean, during which there was a widespread basement uplift and associated high heat flow (Kelly and Wagner 1977).

Basement blocks that did not undergo significant uplift and, consequently, extensive erosion in the Cenozoic, preserve granite and gneiss-hosted swarms of fluorite and barite-rich veins with noticeable amounts of sphalerite and galena (Fig. 2e, f). In the westernmost EICS (Fig. 1), thermodynamic modelling, fluid inclusion and isotope geochemistry studies demonstrate that these veins formed by the mixing at shallow depths $(<1 \mathrm{~km})$, of a low salinity $\left(<3.4 \mathrm{wt} \% \mathrm{NaCl}\right.$ eq.) relatively acid and hot $\left(>300^{\circ} \mathrm{C}\right)$ upflowing aqueous fluid, and a cooler $\left(<100^{\circ} \mathrm{C}\right)$ descending more saline ( $>14 \mathrm{wt} \% \mathrm{NaCl}$ eq.) brine of possible marine origin (Tornos et al. 1991). Sm-Nd dating of fluorite has provided an age of $145 \pm 18 \mathrm{Ma}$ (Galindo et al. 1994b). Veins are thus related in time with the phyllic alteration referred to above; in fact, these veins enclose fragments of episyenites and their selvages that often display phyllic and chloritic alteration.
In the easternmost part of the EICS, an area with silver-rich barite veins exists (Hiendelaencina Dis rict). The origin of these veins has been the subject of debate; they have been interpreted as Variscan epithermal, andesite-related hydrothermal rocks or Alpine basement cover veins unrelated to magmatic activity (Concha et al. 1992; Tornos et al. 1993b).

\section{Event IV (100 \pm 6 to $2010 \mathrm{Ma}$; Cretaceous and Miocene $)$}

The major hydrothermal activity is represented by, at least some of, the barren quartz veins that are common in the EICS (Caballero et al. 1992). Probably synchronous with this stage is the formation of low-temperature jasperoid replacements of marbles adjacent to these faults. The age is similar to ages found elsewhere in the Iberian Peninsula (e.g., Casquet et al. 1992a) apparently related with a rotation of the Iberian Peninsula along the North Pyrenean Fault during the Upper Cretaceous. Details of this event in the EICS are still unclear, although the fluids involved seem to have very variable salinities ( $35 \mathrm{wt} \% \mathrm{NaCl}$ eq.) and are rich in $\mathrm{Ca}$. $\mathrm{Cl} / \mathrm{Br}$ ratios are similar to those of seawater (Martin Crespo et al. 1997). The involvement of seawater in the formation of these veins is not unexpected as in the area there are unconformable marine sediments of the same age.

Finally, there is multiple evidence of younger reactivation of the faults, including $\mathrm{K} / \mathrm{Ar}$ ages in the clay-rich selvages of the fluorite veins and barren fractures.

\section{Analytical methods}

Minerals were separated by crushing and handpicking, after a thorough perographic and microthermometric study of the samples (Tornos 1990). Isotope analyses were primarily carried out at the Stable Isotope Laboratories of the Estación Experimental del Zaidín (CSIC, Granada, Spain). Silicate samples (10 $15 \mathrm{mg}$ ) were reacted with a stoichiometric excess of $\mathrm{ClF}_{3}$ at $650^{\circ} \mathrm{C}$ for $12 \mathrm{~h}$ (Borthwick and Harmon 1982; Venneman and Smith 1990). The oxygen released was converted to $\mathrm{CO}_{2}$ by reaction with a hot platinized graphite rod (Clayton and Mayeda 1963).

Thermal decrepitation of $13 \mathrm{~g}$ of mineral concen rates (quartz, pyroxene and barite, crushed down to $0.51 .0 \mathrm{~mm}$ ) was chosen as the method of extracting fluid inclusions for stable isotope analysis. Hydrogen isotope analysis of fluid inclusions was carried out on quartz, pyroxene and barite. For the hydrogenisotope analyses, a uranium line was used, with a similar methodology to that described by Godfrey (1962). Samples were degassed by heating overnight at $70^{\circ} \mathrm{C}$ under high vacuum. The platinum crucible was then heated (by a radio-frequency induction furnace) to approximately $1200^{\circ} \mathrm{C}$. Non-condensable gases (mainly $\mathrm{CH}_{4}$ and $\mathrm{N}_{2}$ ) were separated cryogenically and pumped away. The released water was converted to hydrogen by passing 
over uranium metal at about $800^{\circ} \mathrm{C}$. For oxygen-isotope analysis of fluid inclusions in fluorite $13 \mathrm{~g}$ of the sample was used. Sample pre-treament consisted of pre-fluorination at $100^{\circ} \mathrm{C}$ for $1 \mathrm{~h}$ (in nickel chambers) after evacuation at high vacuum. The $\mathrm{ClF}_{3}$ and any gases that might have been produced by the reaction were then expelled. The sample was then further degassed for $1 \mathrm{~h}$ (at high vacuum), after which the chambers were closed and the sample was heated for $45 \mathrm{~min}$ at a temperature of $750800^{\circ} \mathrm{C}$, thus releasing the water from the inclusions. Once the chamber had cooled to a temperature of between 70 and $100^{\circ} \mathrm{C}, \mathrm{ClF}_{3}$ was introduced and the temperature maintained for about 30 min (i.e., more than enough ime for the $\mathrm{ClF}_{3}$ to react with the water) in order to free oxygen, which was later converted into $\mathrm{C}_{2}$ via the classic reaction between oxygen and graphite with a platinum catalyst (Clayton and Mayeda 1963). The isotope ratios were measured in a Finnigan MAT 251 mass spectrometer. Commercial $\mathrm{CO}_{2}$ was used as the internal standard for the oxygen analyses of silicates and fluid inclusions, calibrated against the V-SMOW, SLAP and GIPS water standards, thus giving a value of $\delta^{18}=+5.1 \pm 0.2 \%$ for NBS-3॰ (biotite) and $+\mathbf{9} .6 \pm \mathbf{0} .1 \%$ for the NBS-28 (quartz). For hydrogen-isotope analyses water was used that had previously been calibrated against the above-mentioned international water standards.

$\delta^{34} \mathrm{~S}$ analyses were performed at NIGL, Keyworth, UK, following the methodology of Robinson and Kusakabe (1975). The $\delta^{18}$ in sulphates was measured at the Isotopic Geochemistry Laboratory of the Università degli Studi, in Trieste, Italy. The technique used was the reduction of $\mathrm{BaS}_{4}$ with graphite, to release $\mathrm{CO}_{2}$, according to the method proposed by Longinelli (1968). Isotope analyses were carried out with a Finnigan MAT Delta-S spectrometer. NBS-127 gave $\delta^{18}$ values of $+9.15 \%$

The $\delta \mathrm{D}_{\mathrm{H}_{2}} \bullet$ value of the fluid inclusions can be increased from the original values by diffusion of hydrogen outwards from the fluid inclusions (Mavrovenges and Bodnar 1994). However, appreciable outwards diffusion of hydrogen is not to be expected at temperatures below $350^{\circ} 400^{\circ} \mathrm{C}$, i.e., the temperature of trapping of most fluid inclusions (Vityk, personal communication)

and $\delta \mathbf{D}$ values of rocks and minerals are listed in the Table 3. Data are reported in $\delta$-notation relative to SMOW $(-\mathrm{H})$ and CDT (S). Uncertainty is below $\pm 2 \%$ for $\delta^{18}, \pm 3 \%$ for $\delta \mathrm{D}$ and $\pm .1 \%$ for sulphur. The temperature of formation has been estimated from different geothermometers, including fluid inclusion homogenization and chlorite, white mica and sulphide geothermometry (Table 1). As discussed below, most of the isotope pairs show non-equilibrium precipitation. Variations in the calculated $\delta^{18}-\delta \mathbf{D}_{\text {fluia }}$ caused by temperature changes in each hydrothermal event can be important and, thus, the calculated fluid isotope composition is based on a temperature range rather than on an average value. The estimation of the isotope fluid composition in a temperature range minimizes the error caused by fractionation factors or by analytical errors.

\section{Isotopic composition of the host rocks}

The host rocks for most of the hydrothermal alterations and veins are granitoids, largely granodiorites and monzogranites. They have $\delta^{18} \mathrm{O}$ values between 7.3 and 10.4\%. (Aparicio et al. 1986; Recio et al. 1992). Granites s.s. have slightly heavier compositions, 10.1 to $11.5 \%$. Most isotopic compositions are within the range typical of Variscan granites $(9.5$ to $13 \%$; Sheppard 1986a; see also Hoefs and Emmermann 1983; Delgado 1993). Moreover granites s.s. plot in the field of ${ }^{18} \mathrm{O}$-enriched granites (Taylor and Sheppard 1986), suggesting that a pelitic component is present in the more acid terms, as is also evident from the $\mathrm{Sr}$ isotope compositions (Ibarrola et al. 1988). Occasionally, mineralization is hosted by orthogneisses. These rocks have $\delta^{18} \mathrm{O}$ values between 6.9 and $11.6 \%$ (Aparicio et al. 1986), i.e., values similar to granitoids. Recio et al. (1992) found $\delta^{18} \mathrm{O}$ values between 10.7 and $13.8 \%$ in Precambrian metasediments west of the studied area. Hydrogen isotope determinations are very scarce. Biotite from a microporphyritic granite related to a W-Sn greisen-type alteration has provided a $\delta \mathrm{D}$ value of $-78 \%$, which is within the range of values of biotites ( -93 to $-49 \%$ ) from granites from the western Iberian Central System (Recio et al. 1992).

Present-day meteoric waters (rainwater, wells and springs) of central Spain show a considerable spread $\left(\delta^{18} \mathrm{O},-8.9\right.$ to $-6.7 \% ; \delta \mathrm{D},-61$ to $-40 \%$; Reyes et al. 1995; Recio et al. 1992) in response to variations in the altitude and interaction with rocks.

\section{Stable isotopic composition of the hydrothennal rocks}

\section{Event I}

The isotopic composition of the fluids appears to be very variable during this event. In the $\mathrm{Sn}-\mathrm{W}$ skarn the calculated $\delta^{18} \mathrm{O}$ and $\delta \mathrm{D}$ fluid values $\left(\delta^{18} \mathrm{O}, 7.37 .8 \% ; \delta \mathrm{D}\right.$, -77 to $-74 \%$; Table 3 ) for the early diopside are very different to those calculated for the late magmatic muscovites in the nearby granite $(6.46 .6 \% ;-31$ to $-23 \%$ ). Quílez (1994) published some data from the W-(Sn) quartz veins (Garganta and Cabeza Lijar). The $\delta^{18} \mathrm{O}$ of wolframites $(1.9$ and $3.7 \%$ ) suggest a $\delta^{18} \mathrm{O}_{\text {fluid }}$ of 4.7 and $6.9 \%$. These values are lighter than those calculated for the fluid in equilibrium with associated quartz $(7.39 .3 \%)$ that yields $\delta \mathrm{D}_{\text {fluid }}$ values of -35 and $-33 \%$ and indicates that the wolframite precipitated from fluids is more ${ }^{18} \mathrm{O}$-depleted than the quartz. The distal $\mathrm{Zn}$-(W) skarn has $\delta^{18} \mathrm{O}-\delta \mathrm{D}_{\text {fluid-depleted fluid }}$ values $(-0.4$ to $3.4 \% ;-65$ to $-52 \%$ ) whilst the early assemblage of the Fe-rich calcic skarn formed from fluids with $\delta^{18} \mathrm{O}-\delta \mathrm{D}$ values of $-\mathbf{0 . 2}$ to 2.2 and -75 to $-58 \%$, respectively.

\section{Event II}

Isotope composition of minerals in the episyenite was determined by Caballero (1993). If retrograde minerals (e.g., chlorite and epidote) are excluded, calculated fluid compositions are very variable $\left(\delta^{18} \mathrm{O}=-3.6\right.$ to $9.3 \%$. and $\delta \mathrm{D}=-77$ to $-13 \%$ ). In contrast, $\delta^{18} \mathrm{O}$ values in quartz and phyllosilicates from the Navalcubilla greisen system are more homogeneous with calculated $\delta^{18} \mathrm{O}_{\text {fluid }}$ values between 2.1 and $4.9 \%$, and $\delta \mathrm{D}$ values of fluid inclusions between -51 and $-40 \%$. The calculated $\delta^{18} \mathrm{O}_{\text {fluid }}$ composition of the retrograde alteration in the $\mathrm{El}$ Caloco $\mathrm{Fe}$ skarn shows a progressive increase in the ${ }^{18} \mathrm{O}$ content of the fluids during the evolution of the skarn from values close to $\%$ in the early stages to 4.1 
Table 3 Contd.

\begin{tabular}{|c|c|c|c|c|c|c|}
\hline Sample & Description & \multicolumn{2}{|c|}{ Sample } & $\mathrm{T}, \bullet^{\bullet} \mathrm{C}$ & \multicolumn{2}{|l|}{ Fluid } \\
\hline $\begin{array}{l}\text { Event IV } \\
\text { OP-168-1 } \\
\text { OP-168-2 }\end{array}$ & $\begin{array}{l}\text { Late replacement of marbles. Ahnadenes (chalcedony) } \\
\text { Late replacement of marbles. Ahnadenes (chalcedony) }\end{array}$ & $\begin{array}{l}3.8 \\
4.7\end{array}$ & & $\begin{array}{l}150 \\
150 \\
180\end{array}$ & $\begin{array}{l}-11.7,-9.2 \\
-10.8,-8.3\end{array}$ & \\
\hline
\end{tabular}

${ }^{a}$ From Quílez (1994)

${ }^{b}$ Analysis on fluid inclusions

${ }^{c}$ Assuming quartz as the dominant phase (Tornos 1990). The temperature of equilibration is estimated from the Table 1. Fractionation factors. Oxygen: igneous rocks, Cole (1992, 1994); hedenbergite, diopside, andradite, actinolite, pargasite, quartz,

$4.2 \%$ during the formation of the amphiboles and 5.8 $6.3 \%$ in the fluids in equilibrium with the late magnetite.

\section{Event III}

$\delta^{18} \mathrm{O}_{\text {fluia }}$ values, calculated from the $\delta^{18} \mathrm{O}$ analyses of quartz in the hydrothermally altered shear zones, are between 0.6 and $5.3 \%$. Data from feldspars, actinolite and chlorite suggest equilibrium with fluids with heavier $\delta^{18} \mathrm{O}$ values than those expected if in equilibrium with cogenetic quartz $(3.5$ 6.6\%; $5.66 .3 \%$ and $5.37 .6 \%$, respectively; Table 3 ). A highly deformed chloritite replacing the ultracataclasites in the core of a shear zone gave negative $\delta^{18} \mathrm{O}_{\text {fluid }}$ values $(-1.8$ to $-1.1 \%$ ). The unreplaced silica-rich ultracataclasites gave even more negative $\delta^{18} \mathrm{O}_{\text {fluid }}$ values ( -4.6 to $-2.5 \%$ ). Two fluid inclusion analyses gave $\delta \mathrm{D}$ values of -51 and $-45 \%$.

$\delta^{18} \mathrm{O}$ isotopes in quartz, barite and fluid inclusions in fluorite suggest $\delta^{18} \mathrm{O}_{\text {fluid }}$ values of between -6.7 and $5.8 \%$, with strikingly homogeneous $\delta^{18} \mathrm{O}$ values of barites from the eastern and western districts $(8.1 \quad 11.1 \%$ and $10.010 .3 \%$, respectively). The $\delta \mathrm{D}$ signatures of fluid inclusions in quartz, fluorite and barite are between -66 and $-36 \%$.
Zheng (1993); K-feldspar, biotite-phlogopite, tremolite, Caballero (1993); muscovite, Sheppard and Gilg (1996); wolframite, Zheng (1992); magnetite, Zheng (1991); barite, Friedman and O'Neil (1977). Deuterium: biotite, phlogopite, Suzuoki and Epstein (1976); tremolite, Graham et al. (1984)

\section{Event IV}

The only stable isotope data are from the replacive silica in marbles. The estimated $\delta^{18} \mathrm{O}_{\text {fluid }}$ values are very negative, between -11.7 and $-8.3 \%$.

\section{The sulphur isotope composition of sulphides and sulphates}

The sulphur isotopic composition of sulphides from events I to III is very homogeneous and almost all values lie between -3.6 and $\mathbf{0 . 3 \%}$ (Table 4 ). Sulphides from the basement-cover veins of the western district are similar to the previous ones $\left(\delta^{34} \mathrm{~S}\right.$ between -3.4 and $+4 \%$; Lillo et al. 1992; Galindo et al. 1994b) whereas those of the eastern district have $\delta^{34} \mathrm{~S}$ values between 2.9 and $6.7 \%$ (Concha et al. 1992). The barites from the eastern and western districts also have different $\delta^{34} \mathrm{~S}$ values. In most of the veins in the EICS they range between 12.2 and $16.5 \%$. (Lillo et al. 1992) whereas those of the eastern district have values between 6.2 and 26.1\%. (Concha et al. 1992). A stratabound barite in the Permian sediments has a $\delta^{34} \mathrm{~S}$ value of $16.4 \%$.
Table 4 Sulphur isotopic composition of sulphides related with events I and III. Complementary data on the fluoritebarite veins can be found in Lillo et al. (1992), Concha et al (1992) and Galindo et al. (1994b)

\begin{tabular}{|c|c|c|c|c|}
\hline Sample & Description & $\delta^{34} \mathrm{~S}$ & TEC & $\delta^{34} \mathrm{~S}_{\text {fluid }}$ \\
\hline \multicolumn{5}{|l|}{ Event I } \\
\hline C-72 & W-quartz vein in Navalcubilla pluton (molybdenite) & -3.6 & 400550 & $-4.6-4.3$ \\
\hline REV-1 & Calcic distal skarn Revenga (sphalerite) & -0.2 & 400500 & -0.4 \\
\hline REV-2 & Calcic distal skarn Revenga (sphalerite) & $-\mathbf{0 . 7}$ & 400500 & -0.9 \\
\hline REV-12 & Calcic distal skarn Revenga (sphalerite) & $\bullet .2$ & 400500 & $\bullet .0$ \\
\hline \multicolumn{5}{|l|}{ Event III } \\
\hline OS-4 & Late calcic skarn on shear band Ahnadenes (sphalerite) & $-\mathbf{0 . 1}$ & 300350 & $-\mathbf{0} 4$ \\
\hline OP-158 & Late calcic skarn on shear band Ahnadenes (chalcopyrite) & -1.6 & 300350 & $1.5-1.4$ \\
\hline P-158-1 & Late calcic skarn on shear band Ahnadenes (chalcopyrite) & 0.0 & 300350 & 0.10 .2 \\
\hline OP158-2 & Late calcic skarn on shear band Ahnadenes (chalcopyrite) & 0.3 & 300350 & 0.4 \\
\hline OS-93 & Late calcic skarn on shear band Ahnadenes (chalcopyrite) & $-\bullet .2$ & 300350 & $-\bullet .1$ \\
\hline P-262 & Late calcic skarn on shear band Ahnadenes (chalcopyrite) & $-\mathbf{0 . 7}$ & 300350 & $-0.6-0.5$ \\
\hline GC-1 & Permo-triassic cover sequence (barite) & 16.4 & & 16.4 \\
\hline
\end{tabular}




\section{Interpretation and discussion}

The isotopic composition of fluids involved in the hydrothermal events in the Eastern Iberian Central System covers a wide range that partly overlaps the fields of magmatic and metamorphic (i.e., deep waters) as well as modified surficial waters (e.g., Taylor 1979; Sheppard 1986b). There is no obvious trend related to the age, temperature or depth of formation. However, geological and age constraints allow two major hydrothermal histories to be distinguished. The event $\mathrm{I}$ is related (within the error of the age determinations) to the waning stages of the granitic magmatism. The second, which includes events II to IV, is independent of magmatism. In the first case, hydrothermal flow was probably driven by the heat from the cooling intrusions. In the second case, fluid flow was driven by thermal anomalies related to regional deformation of the brittle basement during rotation of the Iberian Peninsula in the Mesozoic and Cainozoic times.

Fig. $3 \delta^{18} \mathrm{O}-\delta \mathrm{D}$ diagram for hydrothermal fluids in the Eastern Iberian Central System a event I $(295 \pm 10 \mathrm{Ma})$. The field of metamorphic waters of the SCS has been constructed at $400-550{ }^{\circ} \mathrm{C}$ using the $\delta^{18} \mathrm{O}$ signatures of gneisses from Aparicio et al. (1986) and the $\delta \mathrm{D}$ values of metasedimentary rocks of Recio et al. (1992). The distillation curve is calculated at $500{ }^{\circ} \mathrm{C}$ for a magmatic fluid with a composition of $\delta^{18} \mathrm{O}=12 \%$ and $\delta \mathrm{D}=-50$ that precipitates quartz and muscovite at equivalent $f$ values in a Rayleigh process. The slope is only indicative and assumes that all the $\delta^{18} \mathrm{O}$ and $\delta \mathrm{D}$ fractionate with quartz and muscovite, respectively, with a similar $f$ value. The exact trend depends on multiple variables including the quartz/ muscovite ratio and exchange and growth rates. The reaction curve is for a granite in equilibrium with this magmatic fluid at $600{ }^{\circ} \mathrm{C}$ and a modified meteoric one with $\delta^{18} \mathrm{O}=0 \%$ and $\delta \mathrm{D}=-75 \%$. b Events II to IV $(274 \pm 7 \mathrm{Ma}, 154 \pm 12$ and younger than $101 \pm 4 \mathrm{Ma})$ The fields of the hydrothermal fluids have been calculated excluding the data of feldspars and chlorite from the phyllic and chloritic alteration (see text). The data on the episyenites is from Caballero (1993) excluding the late minerals (epidote, chlorite). Basement cover veins: $E$ eastern zone (Hiendelaencina district); $W$ western zone (Colmenar de Arroyo district). The fluid/rock interaction curves are calculated for a meteoric fluid with a composition of -9.4 to $-5.6 \%\left(\delta^{18} \mathrm{O}\right)$ and -65 to $-36 \%(\delta \mathrm{D})$ with gradual equilibration with the granitoids of the $\operatorname{ESCS}\left(\delta^{18} \mathrm{O}=7.3\right.$ to $11.5 \% ; \delta \mathrm{D}=-78$ to $\left.-70 \%\right)$ at $300{ }^{\circ} \mathrm{C}$, assuming that the $\delta \mathrm{D}$ values are controlled by muscovite. Fractionation factors from Table 3. ICS Iberian Central System

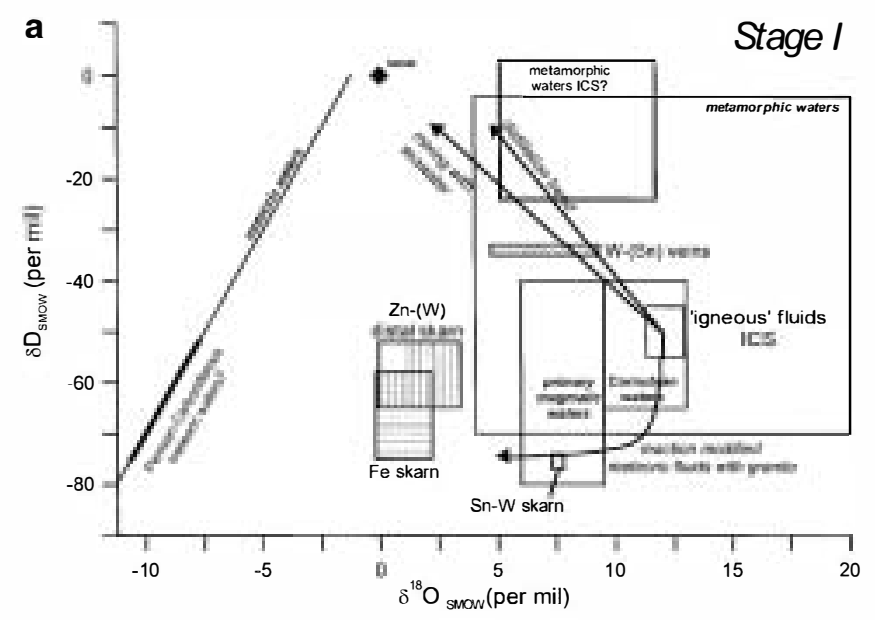

The origin of the event I fluids: involvement of magmatic fluids in the system?

The event I hydrothermal rocks are spatially and chronologically related to the late granitic intrusions. They are interpreted as forming in relation with hydrothermal cells in the roof zones of small intrusions (stocks and dykes).

Isotope data of event I hydrothermal rocks plot in very different areas in the $\delta^{18} \mathrm{O}-\delta \mathrm{D}$ diagram (Fig. 3a), suggesting the involvement of fluids with very variable origins. The isotope composition of the magmatic fluids can be estimated from the data on the EICS granites. Assuming an exsolution temperature of $700-750{ }^{\circ} \mathrm{C}$ (Tornos et al. 1993a), the calculated isotope composition of the fluids is $\delta^{18} \mathrm{O}=11.3-12.9 \%$ and $\delta \mathrm{D}=-55$ to $-45 \%$, within the field typical of fluids evolved from late Variscan granitoids in Cornwall (Sheppard 1986b). These values do not match any of the $\delta^{18} \mathrm{O}-\delta \mathrm{D}$ fields of the mineralization (Fig. 3a). However, magmatic fluids can have $\delta^{18} \mathrm{O}$ values as low as $6 \%$ caused by progressive re-equilibration with the intrusive during cooling (e.g., Smith et al. 1996).

The $\delta^{18} \mathrm{O}-\delta \mathrm{D}$ plot (Fig. 3a) shows that metamorphic fluids were not involved in the genesis of the Sn-W skarns. The $\delta^{18} \mathrm{O}_{\text {fluid }}$ values calculated from samples CD-23 could well indicate involvement of fluids equilibrated at $500-600{ }^{\circ} \mathrm{C}$ with the host granites $\left(\delta^{18} \mathrm{O}=6.5\right.$ $12.5 \%$ ), the nearby ${ }^{18} \mathrm{O}$-depleted monzogranites $\left(\delta^{18} \mathrm{O}_{\text {fluid }}=7.0-7.9 \%\right)$ or orthogneisses $\left(\delta^{18} \mathrm{O}_{\text {fluid }}=6.5\right.$ $12 \%$ ). However, a Rayleigh distillation of the magmatic fluids during precipitation of minerals (i.e., quartz) along the fluid path could explain the observed $\delta^{18} \mathrm{O}$ signatures, although. any distillation process with formation of hydrogen-bearing minerals (e.g., micas, amphiboles) would lead to heavy $\delta \mathrm{D}$ signatures well above the recorded $-75 \%$ values. Low $\delta \mathrm{D}$ values can only be expected in magmatic systems where phase separation occurs, with a concomitant deuterium enrichment in the gas phase (Hedenquist et al. 1998). Low salinities (2$10 \mathrm{wt} \%$ ) are only expected in magmatic fluids exsolved at intermediate to great depths because they do not unmix (Shinohara and Khazahaya 1995). Thus, the

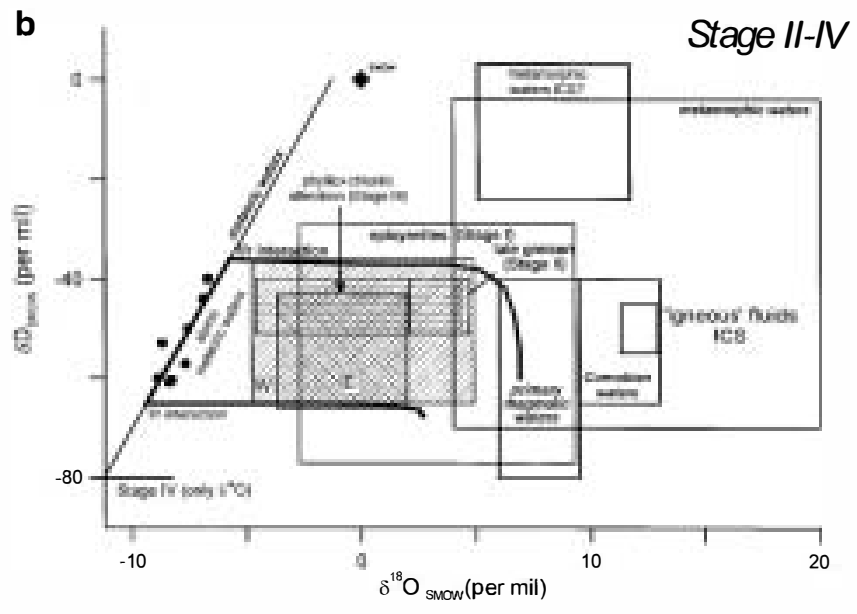


presence of low $\delta \mathrm{D}$-low salinity fluids excludes a deep origin for the fluids.

The Sn-W skarns formed in a deep and hot environment $\quad\left(\mathrm{T}=500600{ }^{\circ} \mathrm{C} ; \quad \mathrm{P}_{\text {fluid }}=\mathrm{P}_{\text {lit }} \approx 2.53 \mathrm{~kb}\right)$ where the inflow of meteoric fluids was apparently restricted. However, the fluid inclusion and isotope values could represent equilibration of external fluids with the nearby metamorphic rocks prior to the reaction with the marbles. $\mathrm{Nd}$ and $\mathrm{Sr}$ isotope data are consistent with this hypothesis because the Nd and initial ${ }^{87} \mathrm{Sr} /{ }^{86} \mathrm{Sr}$ ratios reflect a source external to the granites, probably the host gneisses (Casquet et al., in preparation). The intrusion of the late granites took place under conditions of regional compression with strike-slip faults and local development of extensional fractures. In this tectonic setting, meteoric fluids could have percolated deep into the crust and become involved in the hydrothermal cells. Late incursion of meteoric waters in orogenic belts is well recorded in ancient and recent systems (Nesbitt et al. 1986; Craw and Chamberlain 1996) with the hydrostatic head created by topography above a developing and uplifting metamorphic belt.

The other skarns ( $\mathrm{Fe}$ and $\mathrm{Zn}$ - $(\mathrm{W})$ calcic skarns) formed at shallower depths and are characterized by lower $\delta^{18} \mathrm{O}$ but similar $\delta \mathrm{D}$ values. The ${ }^{18} \mathrm{O}$-depleted values of these fluids suggest that, again, modified meteoric fluids had to be involved. This interpretation is consistent with the shallow depth and low temperature of formation as well as the composition of fluid inclusions in the $\mathrm{Zn}-(\mathrm{W})$ skarns. Distal Zn-rich skarns similar to these ones are typically interpreted as related with the circulation of meteoric fluids away from major intrusions (Einaudi et al. 1981). The high salinity of the ferric skarns is interpreted as caused by boiling (Tornos et al. 1995) and does not represent the original composition of the fluid.

The negative $\delta \mathrm{D}$ values ( -75 to $-52 \%$ ) are within the -125 to $-36 \%$ range found by Campbell et al. (1984) in Panasqueira, and are interpreted as the result of the interaction of highly D-depleted meteoric waters of Carboniferous Permian age with the host rocks. The very negative values are not consistent with the nearequatorial situation of the Iberian Peninsula during those times (Ziegler et al. 1983) as more positive values should be expected (Rozanski et al. 1993), unless the systems were recharged at high altitudes or far away from the sea where $\delta \mathrm{D}$ values are significantly lower (Sheppard 1986b). Very negative $\delta \mathrm{D}$ values during Permo-Triassic times have been explained by Mutti and Weissert (1996) as caused by a monsoonal climate (Parrish et al. 1982) in Pangea.

The W-(Sn) veins (samples 3833 and those of Quilez 1994) plot in a field characterized by significantly higher $\delta \mathrm{D}$ values but intermediate $\delta^{18} \mathrm{O}$ values. Several mechanisms can explain these compositions including (1) interaction of seawater with the granites, (2) a Rayleigh fractionation of the magmatic fluids and (3) a precipitation from an immiscible magmatic gas phase (Fig. 3a). The dominant fluids belong to the $\mathrm{H}_{2} \mathrm{O}-\mathrm{CO}_{2}-$
$\mathrm{CH}_{4}-\mathrm{NaCl}$ system, with a complex evolution characterized by complex mixing unmixing processes and redox variations (Quílez 1994; Vindel et al. 1995). Hypersaline brines of presumed magmatic origin are only anecdotal. The fluid compositions are typical of medium- to high-grade metasedimentary rocks (e.g., Roedder 1984; Mullis et al. 1994) as are the rocks intruded by the granites. The $\delta \mathrm{D}$ data $\left(\delta \mathrm{D}_{\text {fluid }}>-24 \%\right)$ are more consistent with this origin than with the participation of a more deuterium-depleted magmatic brine. The quartz $\delta^{18} \mathrm{O}$ values (7.3 9.3\%) can be readily explained as caused by the influx of these fluids at $400550^{\circ} \mathrm{C}$. The wolframites have lower $\delta^{18} \mathrm{O}$ values, suggesting precipitation at lower temperatures.

The event II and the onset of the Alpine cycle in central Iberia

The differences between stages I and II are caused by a dramatic change in hydrodynamic, geologic and geochemical conditions. During event II, the hydrothermal alteration was focused primarily along major tectonic discontinuities. Regional scale hydrothermal cells were formed, involving large amounts of hot $\mathrm{CO}_{2}$-poor lowsaline waters by free convection and under nearhydrostatic conditions (Tables 1 and 2).

The first evidence of this change, at a regional scale, occurred at about $274 \pm 7$ Ma marking the onset of the Alpine cycle (González Casado et al. 1996). Incursion of meteoric waters through the plutonic rocks was controlled by the $400{ }^{\circ} \mathrm{C}$ isotherm that defines the brittleductile transition in granites (Giggenbach 1995) and thus, the capability of maintaining significant fluid fluxes. In the W-(Sn) veins there is evidence that in some systems the late sulphide-rich stage was dominated by $\dot{\mathrm{H}}_{2} \mathrm{O}-\mathrm{CH}_{4}$ metamorphic? fluids (Vindel et al. 1995), whereas in shallower systems low salinity aqueous fluids dominated (Navalcubilla; Table 1; Tornos et al. 1993a).

\section{The origin of event II and III fluids}

During events II and III, two main groups of hydrothermal systems can be distinguished: (1) relatively deep systems where the usually replacive hydrothermal assemblage precipitated because of fluid/rock interaction and local boiling (they include episyenites, skarns, greisens and phyllic and chlorite-rich replacements near shear zones) and (2) shallow fluorite-barite ( $\mathrm{Pb}-\mathrm{Zn}-\mathrm{Ag}$ ) veins of the basement-cover type. Because of uplift and erosion of the blocks forming the SCS from event II to the present, the surficial equivalents of these hydrothermal systems are missing.

Hydrothermal rocks of the first type record a wide range of $\delta^{18} \mathrm{O}$ values from slightly negative to positive, typical of surface-derived hydrothermal waters that partially equilibrated with deep rocks (Fig. 3b; e.g., Taylor 1979; Sheppard 1986b). The $\delta^{18} \mathrm{O}$ shift of the 
local waters depends on the temperature, fluid/rock ratio, the difference between the $\delta^{18} \mathrm{O}$ composition of the rock and that of the fluid, and if the system is open or closed (e.g., Cole 1994). Progressive enrichment in $\delta^{18} \mathrm{O}$ in meteoric fluids with increasing temperature due to water-rock interaction is also well documented in hydrothermal systems in active mountain belts (Jenkin et al. 1994). The more ${ }^{18} \mathrm{O}$-enriched values ( $>\approx 3 \%$ ) can only be explained as resulting from the equilibration at low fluid/rock ratios with the host rocks, granites or gneisses. The lower values reflect more fluid dominated systems.

The ultracataclasites (samples OS-101) in the major faults have $>\mathbf{8 0} \mathrm{wt} \%$ quartz and are characterized by very low $\delta^{18} \mathrm{O}$ values, indicating that the fluids had $\delta^{18} \mathrm{O}_{\text {fluid }}$ values between -4.6 and $-2.5 \%$, only about $3.34 .8 \%$ above the composition of local meteoric waters (see below). Because the fluid/rock ratios in these systems must be extremely high these values probably reflect the isotope composition of the upwelling fluids. Around these structures there is a pervasive alteration halo of about $2030 \mathrm{~m}$. Feldspars and micas are irregularly replaced by phengite and chlorite synchronously with a silicification. In these lateral replacement zones the fluid/rock ratio was significantly lower and the fluid in equilibrium with the rock had higher $\delta^{18} \mathrm{O}$ values, between 0.6 and $4.3 \%$. The importance of fluid/rock interaction in these systems is also demonstrated in $\mathrm{El}$ Caloco skarn where there is a systematic increase in the calculated $\delta^{18} \mathrm{O}$ of the fluid in equilibrium with skarn as the system progrades (Samples KS-2, KS-7 and 12704; Table 3).

Another major feature is that in these shear zones the quartz is in isotopic disequilibrium with the associated minerals, having ${ }^{18} \mathrm{O}$-depleted values comparable to feldspars, actinolite or chlorite, vielding unrealistic $\Delta_{\text {quartz-mineral }}$ values (samples OS-23, OS-34, OS-147, OS-148, BP-12, and BE-16; Table 3). The inferred heavy isotopic composition of fluids in equilibrium with the minerals other than quartz $\left(\delta^{18} \mathrm{O}\right.$ up to $7.2 \%$ ) seems unlikely in this geological context. Such a heavy signature cannot be explained solely by fluid/rock interaction because, in a monzogranite buffered system at $350{ }^{\circ} \mathrm{C}$, the maximum $\delta^{18} \mathrm{O}$ is $7 \%$ and the petrographic and geochemical studies indicate high fluid/rock ratios (Tornos 1990). The isotopic disequilibrium may reflect an incomplete equilibration with late fluids. Several studies show that at temperatures near $400{ }^{\circ} \mathrm{C}$ (Giletti and Yund 1984) the diffusion of oxygen in quartz is negligible and quartz does not equilibrate with hydrothermal fluids unless it is completely recrystallized. Consequently, it retains its original composition. Similar experimental and geological studies carried on feldspars show that they more easily equilibrate at lower temperatures (O'Neil and Taylor 1967; Giletti et al. 1978; Conrad et al. 1995). There are no available data on the behaviour of chlorite but their sheet-like structures strongly suggest that isotopic re-equilibration may also be attained with the cooler fluids circu- lating in the system. Thus, the increase in $\delta^{18} \mathrm{O}$ signatures of minerals other than quartz in the samples OS-23, BP-12, BP-12a and BE-16 is interpreted to be caused by the isotopic equilibration at temperatures lower than that of their formation but higher than $180230^{\circ} \mathrm{C}$.

Only in the greisens, unrelated to major shear bands, does there seem to be isotopic equilibrium between the hydrothermal minerals. The $\Delta_{\text {quartz-muscovite }}$ in the sample C-5 yields temperatures of equilibration of about $332 \pm 25^{\circ} \mathrm{C}$, which are consistent with the temperature of formation of the greisen $\left(250380^{\circ} \mathrm{C}\right)$.

Stable isotope studies in hydrothermal systems show that in $\delta^{18} \mathrm{O}-\delta \mathrm{D}$ space there is usually a horizontal array and the $\delta^{18} \mathrm{O}$ variation is not accompanied by a corresponding shift in $\delta \mathrm{D}$. Numerical models (e.g., Taylor 1979; Criss and Taylor 1986) demonstrate that the $\delta \mathrm{D}$ shift can only be detected at very low fluid/rock ratios because of the low content of hydrogen in the rocks $(\approx 0.1 \%)$ compared with oxygen $(11.1 \%)$. This buffered behaviour of hydrogen is an invaluable tracer for the origin of surficial fluids, since meteoric waters can be easily distinguished from marine ones (Sheppard 1986b). In the EICS the $\delta \mathrm{D}$ values of stage II and III fluids are very similar. Those belonging to rocks formed with no noticeable influence of unmodified surficial waters (i.e., others than the fluorite-barite-base metal veins) have $\delta \mathrm{D}$ values between -51 and $-40 \%$, whereas the $\delta \mathrm{D}$ values of basement-cover veins range between -65 and $-36 \%$. Both ranges are equivalent and suggest that the fluids that recharged the hydrothermal cells were similar to those of the surface. This range is very similar to that of the late Jurassic (Kelly and Wagner 1977; Thadeu 1982) fluids related to the sulphide and carbonate-rich events of Panasqueira, located about $250 \mathrm{~km}$ west $(\delta \mathrm{D},-55$ to $-43 \%$; Kelly and Rye 1979). They interpreted these $\delta \mathrm{D}$ values as those of local meteoric waters during the late stages of mineralization, in an equatorial but low altitude situation. The good agreement between both sets of data suggests that the meteoric waters of the Central Iberian Peninsula during Early Mesozoic times had $\delta \mathrm{D}_{\text {fluid }}$ values between -65 and $-36 \%$ and $\delta^{18} \mathrm{O}_{\text {fluid }}$ values of -9.4 to $-5.8 \%$. Present-day waters in central Spain show a similar range.

The $\delta \mathrm{D}$ isotopic composition and the low salinity of the deep fluids involved in events II and III suggest that they were meteoric. Palaeogeographic reconstructions are consistent with these results. Virgili et al. (1983) and Capote and Carbó (1983) suggest that this part of the SCS was emergent between, at least, the Upper Carboniferous and the Upper Jurassic. Continental sedimentation took place in tectonic basins in Upper Carboniferous Lower Permian times (Gonzalez-Casado et al. 1996).

In all cases, the fluids were mainly aqueous with low to medium salinities ( $11.5 \mathrm{wt} \% \mathrm{NaCl}$ eq.). These are equivalent to the low salinity aqueous waters that occur systematically as late overprints in almost all the wolframite-cassiterite veins of the Iberian Peninsula (Kelly 
and Rye 1979; Mangas and Arribas 1987; Vindel et al. 1995). However, the solute content of the original fluids must be even lower $(\leq 6 \mathrm{wt} \%)$ because the higher salinities are systematically found in systems where there is evidence of boiling (e.g., Navalcubilla, El Caloco). The fluids are equivalent to the typical chloride waters found elsewhere in liquid-dominated (present and fossil) epithermal and geothermal systems in igneous rocks (e.g., Sheppard 1986b; Cole 1992; Moore and Gunderson 1995) as well as in ore deposits including late stage assemblages in porphyry copper, skarns and vein and greisen-type systems (e.g., Titley and Beane 1981; Jackson et al. 1982; Roedder 1984). An increase in the salinity from the near zero values of meteoric waters should always be expected because of the exchange at low temperatures with the host rocks (e.g., Fritz and Frappe 1982).

The origin of the fluorite-barite $(\mathrm{Pb}-\mathrm{Zn}-\mathrm{Ag})$ veins

Correlation between the low temperature barite-rich veins located in the eastern and westernmost sectors is hindered by the lack of precise chronology. However, some preliminary $\mathrm{Sr}$ and $\mathrm{Pb}$ isotope data indicate that similarities exist between both sectors. The ${ }^{87} \mathrm{Sr} /{ }^{86} \mathrm{Sr}$ ratios for the easternmost veins (Hiendelaencina district) range between $\mathbf{0 . 7 1 9 2}$ and $\mathbf{0 . 7 1 9 5}$ (Darbyshire and Tornos, unpublished data), and are similar to those in the western district ( $\mathbf{0 . 7 1 5 4}$ to $\mathbf{0 . 7 2 0 7})$ consistent with $\mathrm{Sr}$ derived from a high radiogenic source (granites or metamorphic equivalents) and seawater (Galindo et al. 1994b). The $\mathrm{Pb} / \mathrm{Pb}$ isotope ratios are also equivalent (western district: ${ }^{206} \mathrm{~Pb} /{ }^{204} \mathrm{~Pb}=18.4618 .47 ;{ }^{207} \mathrm{~Pb} /$ ${ }^{204} \mathrm{~Pb}=15.6415 .65$; eastern district: ${ }^{206} \mathrm{~Pb} /{ }^{204} \mathrm{~Pb}=$ 18.46; ${ }^{207} \mathrm{~Pb} /{ }^{204} \mathrm{~Pb}=15.65$; Tornos et al. 1998). The similarities between both districts also include the structure and texture of the veins, which have a marked vertical zonation in the mineral assemblage with barite in the uppermost parts, and fluorite or quartz in the lowermost ones. Fluid inclusions in veins of both districts indicate that fluid mixing was a common process (see data in Tornos et al. 1991; Concha et al. 1992). These similarities are also reflected in the $\mathrm{O}-\mathrm{H}$ isotope results (Table 3).

In these basement-cover type veins, the heavier $\delta^{18} \mathrm{O}$ values are similar to those of equivalent systems with no surficial influence. Since barite is a clear marker of the oxidizing boundary because of its insolubility, its $\delta^{18} \mathrm{O}$ data should reflect the maximum $\delta^{18} \mathrm{O}$ value of the surficial fluid. The analysed barites show strikingly constant $\delta^{18} \mathrm{O}$ signatures, mostly between 10 and $11.1 \%$. and indicate $\delta^{18} \mathrm{O}_{\text {fluid }}$ values as low as $-6.7 \%$.

The marine or meteoric origin of the shallow fluid present in ahnost all the fluorite-barite veins of the Variscan Belt of the Iberian Peninsula has remained speculative as $\delta \mathrm{D}$ data were not available (e.g., Canals and Cardellach 1992; Galindo et al. 1994b; Johnson et al. 1996). On the basis of fluid inclusion and Sr iso- tope data, Galindo et al. (1994b) proposed that the surficial waters were downwards percolating marine brines formed in an evaporitic coastal environment located on the actual Eastern Iberian Central System. However, the new $\delta \mathrm{D}$ data suggest that the fluids were meteoric in origin. The $\delta \mathrm{D}$ values in the Table 3 support the alternative but previously discarded model of Galindo et al. (1994b) in which, during the Jurassic Cretaceous, meteoric fluids extensively flowed through Permo-Triassic sediments, leached marine evaporites acquiring the salt and the Sr signature, before percolating along extensional faults and mixing with the deep fluids. The recent $\mathrm{Cl} / \mathrm{Br}$ ratios of the fluid inclusions in fluorite measured by Martin Crespo et al. (1997) are consistent with this hypothesis. The only available evaporites are those belonging to the Keuper facies (Upper Triassic) that form huge outcrops eastwards but have not been recorded on the basement of the Iberian Central System. It may be that they have been eroded away during the repeated post-Variscan erosion.

\section{The stage IV fluids}

The very negative $\delta^{18} \mathrm{O}$ values of the stage IV fluids suggest that they were formed by the circulation of meteoric waters with little or no interaction with the host rocks. In fact, the light $\delta^{18} \mathrm{O}$ values obtained from the sample OP-168 (-11.7 to $-8.3 \%$ ) are lower than those of actual waters in the area (Fig. $3 \mathrm{~b}$ ) and imply $\delta \mathrm{D}$ values as light as -84 to $-56 \%$.

\section{The origin of sulphur in the hydrothermal systems}

The sulphur isotope analyses show that the most likely candidates for sulphur in sulphides are the widespread igneous rocks, granites and earlier orthogneisses, of the area. The close to $\%$ values of sulphides related to the events I, II and deep zones of the stage III $(-3.6$ to $0.3 \%$ ) support this hypothesis. In fact, Recio et al. (1991) have found $\delta^{34} \mathrm{~S}$ values between -3.9 and $4.8 \%$ in magmatic rocks of the western zone of the Spanish Central System.

However, barite from shallow stage III veins of the Colmenar de Arrovo area has $\delta^{34} \mathrm{~S}$ values between 12.2 and $16.6 \%$ (Lillo et al. 1992), indicating that the sulphate was sourced from the descending surficial waters (Galindo et al. 1994b). Paragenetically equivalent sulphides have $\delta^{34} \mathrm{~S}$ values between -4.4 and $0.4 \%$, which are similar to that of the deep hydrothermal systems. The absence of chemical equilibrium between oxidized and reduced sulphur aqueous species leads to unrealistically high isotopic temperatures $\left(325412{ }^{\circ} \mathrm{C}\right.$; Lillo et al. 1992) that are inconsistent with the fluid inclusion data and the low temperature of precipitation of barite elsewhere $\left(<250300{ }^{\circ} \mathrm{C}\right)$. The situation seems to be very different in Hiendelaencina where the few available data (Concha et al. 1992) suggest that oxida- 


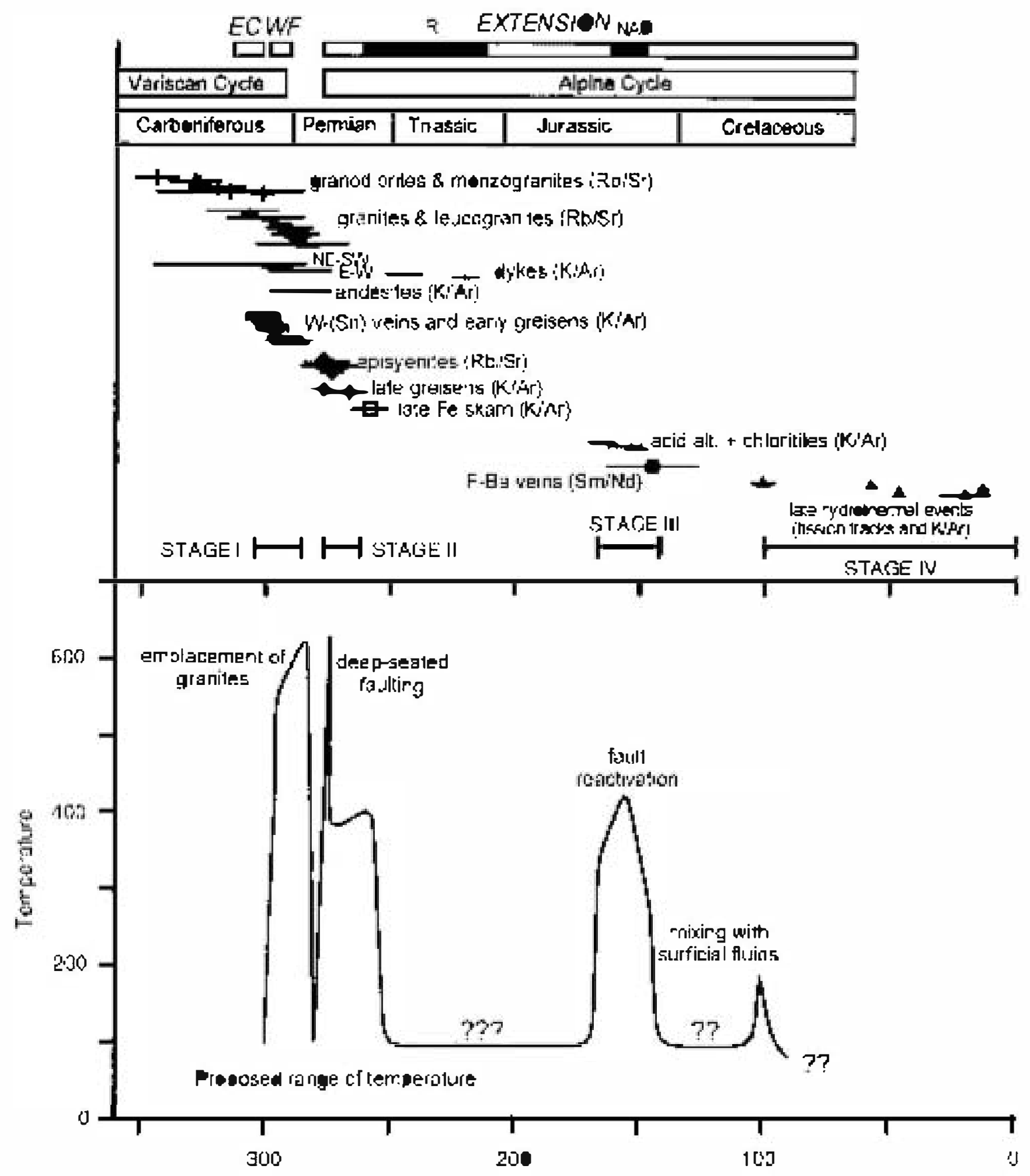

Age vala

Fig. 4 Schematic diagram of the age temperature tectonic evolution of the Late Variscan to Alpine hydrothermal evolution of the Eastern Iberian Cen ral System. Ages are synthesized from data of Ibarrola et al. (1988); Pérez Soba (1991); Casillas et al. (1991); Caballero et al. (1992), Caballero (1993), Galindo et al. (1994a,b), González Casado et al. (1996) and Casquet et al. (in preparation). The tectonic cycles and events are from Caballero et al. (1992) and Gonzalez Casado et al. (1996). EC Extensional collapse; $W F$ wrench faulting. $R$ rifting associated with the formation of Betic, Lusitanian, Catalonian, Pyrenean-Cantabrian basins and the Ibe ria trough; NAO beginning of North Atlanic opening 
tion of deep sulphide took place. Analysed sulphides have $\delta^{34} \mathrm{~S}$ signatures between 2 and $6 \%$, whereas a barite has a signature of $27 \%$; this value is too heavy to have being derived directly from the seawater sulphate and probably suggests an origin from partial oxidation of the deep hydrothermal sulphide. Other nearby barites have $\delta^{34} \mathrm{~S}$ values close to $6 \%$ and in those sulphate was probably derived from the complete oxidation of deep sulphide. This isotopic evolution of sulphur is very similar to that recorded in other basement-cover veins of the Variscan Belt of the Iberian Peninsula (Canals and Cardellach 1992; Johnson et al. 1996).

\section{Conclusions}

In the Eastern Iberian Central System there has been an episodic hydrothermal activity from the Variscan orogeny to the present day (Fig. 4). There are at least four major hydrothermal events, each with its own structural context, mineralogical, isotopic and fluid inclusion signature. They can be correlated with regionally important extensional geotectonic events accompanied by high heat flow (Caballero et al. 1992).

Stage I is characterized by the development of local hydrothermal cells confined to the vicinity of the youngest intrusion of shallow granites. The proportion of magmatic fluids involved in these systems seems to be negligible because of the water-undersaturated character of the intrusions. The mobilized fluids are most likely of metamorphic and modified meteoric origin. These external waters invaded the intrusions soon after they consolidated.

The transition from these spatially confined fluid systems to regional ones occurs at the start of the Alpine orogeny, at about $277 \mathrm{Ma}$ (González Casado et al. 1996). The morphology and chemistry of the hydrothermal systems changes dramatically. There was a generalized intrusion of meteoric fluids into the crust and the hydrothermal systems progressed from highly confined, nearly closed systems dominated by lithostatic pressures, and where fluid was channelled by minor faults, to major convective cells dominated by regional extensional shear zones and faults where the pressure was dominantly hydrostatic. By comparison with present-day systems the size of these cells was likely to be of in the order of $1001000 \mathrm{~km}^{2}$ scale (Chamberlain et al. 1995). The fluids involved were low saline chloride waters of likely meteoric origin with $\delta^{18} \mathrm{O}$ and $\delta \mathrm{D}$ values of -9.4 to -5.8 and -65 to $-36 \%$, respectively, that interacted with the basement at high temperatures $\left(>350^{\circ} \mathrm{C}\right)$, resulting in hot waters with $\delta^{18} \mathrm{O}$ values between -4.6 and $4.9 \%$ and $\delta \mathrm{D}$ values similar to the original ones. There is no relationship between temperature or age of the hydrothermal systems and the isotopic signature.

During tectonic pulses in the Alpine extension, descending meteoric fluids deeply intruded into the crust, were heated to high temperatures and reacted with the igneous and metamorphic rocks leaching metals and sulphur (Fig. 5). After interaction, the fluids rose by convection through the fracture system, leading to hydrothermal alteration and ore precipitation. In these systems, water-rock reaction was the most important process that led to changes in the isotopic composition of fluids prior to boiling or fluid mixing at shallow depths. In the major structures the early and hottest fluids produced episyenites, whereas the later ones pervasively replaced the host rocks, unaltered granites and episyenites or skarns. The dramatic alkalinization of fluids led to the precipitation of metals, preferentially in the skarns or episyenites. Ahnost all the hydrothermal and tectonic evolution described here is found superimposed in the Ahnadenes deposit. The mineralization is located within a WNW ESE shear zone located between granodiorites and marbles partially replaced by stage I distal skarns (Tornos 1990). The rocks ad jacent to the shear zone are affected by episyenitization and younger phyllic and chloritic alteration as well as retrograde skarn formation. This complex hydrothermal evolution led to the effective trapping of metals carried by the hydrothermal fluids and their progressive reconcentration during the different events.

It is noteworthy that in other areas, such as Cornwall, the hydrothermal events are related with the cooling and heat production processes of a single batholith (Jackson et al. 1989) with progressive mixing of magmatic fluids and meteoric ones. In the EICS, the age difference between the intrusion of igneous rocks and the hydrothermal events indicates that the heat flow and related fluid buoyancy were not magmatic in origin but related to high geothermal gradients associated with the tectonic extensional events. These high temperatures cannot be interpreted as related only with high heat production processes because the radioactive decay of granites does not produce temperatures higher than $200{ }^{\circ} \mathrm{C}$ (Fehn 1985).

Systematic dating in the Variscan Belt of Europe has shown that the Late Variscan-Early Alpine hydrothermal activity is very important. Mesozoic ages for the hydrothermal rocks have been recorded in very different areas (e.g., Halliday and Mitchell 1984; Bonhomme et al. 1987; Bril et al. 1991; Chen et al. 1996; Krahn and Baumann 1996).

In the shallow parts of the hydrothermal systems, boiling or fluid mixing with surficial waters may have occurred but at greater depths fluid-rock interaction seems to be the main mechanism leading to significant volumes of hydrothermal rocks. The fluorite barite $(\mathrm{Pb}-$ $\mathrm{Zn}-\mathrm{Ag}$ ) veins of the eastern and western EICS have similar fluid inclusion, radiogenic $(\mathrm{Pb}, \mathrm{Sr})$ and stable $(\mathrm{O}$, $\mathrm{H}, \mathrm{S}$ ) isotope values suggesting that they formed in equivalent hydrothermal systems. In the veins formed by mixing of the deep fluids with surficial ones, the $\delta \mathrm{D}$ indicate that descending fluids were meteoric waters that leached marine evaporites whereas the deep fluids were equivalent to the hydrothermal fluids responsible for the stage II III hydrothermal alteration. 


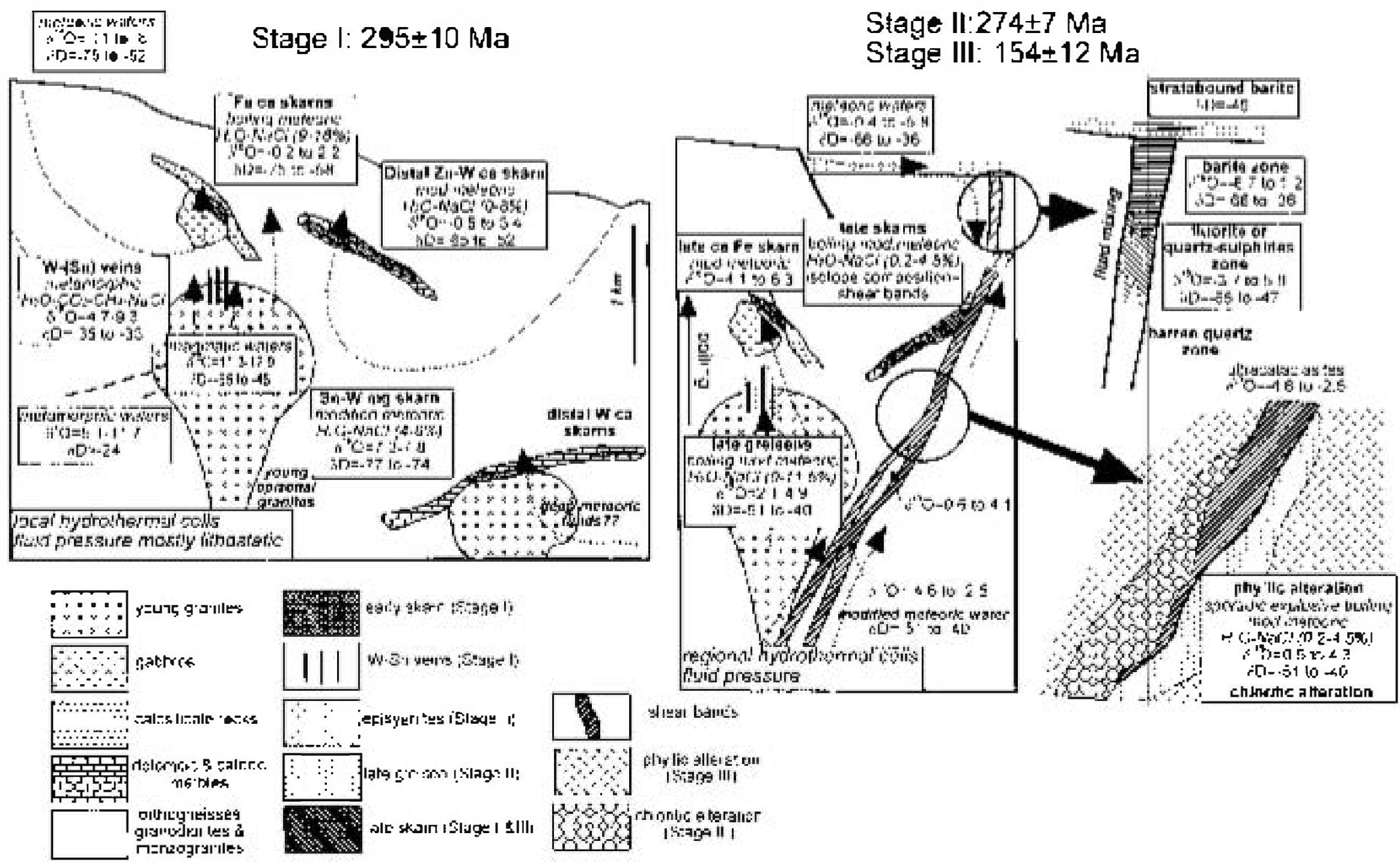

Fig. 5 Cartoon of the Late Variscan to Alpine hydrothermal history of the Eastern Iberian Cencal System based on the existing fluid inclusion and stable and radiogenic isotope data Salinities are in per cent equivalent $\mathrm{NaCl}$ and isotope notations in \%. ca Calcic skarn; $m g$ magnesian skarn 
Quartz, garnet, pyroxene and magnetite retain their original $\delta^{18} \mathrm{O}$ signature. Other minerals such as feldspars or phyllosilicates seem to quickly re-equilibrate with later and cooler fluids that circulated along the major faults; their original signature is only retained in the single stage fluid systems.

Finally, sulphide seems to be derived from the hydrothermal leaching of granites. There is only a significant input of oxidized sulphur of marine origin during the stage III and related with the precipitation of barite.

Acknowledgements This work has been funded by the projects PB88-124 (CIC YT) and PB96-0575 (DGSIC) as well other projects carried by the ITGE in the Spanish Central System. We acknowledge our colleagues Drs González Casado, Caballero and Quílez for their facilities in using unpublished data and their collaboration in the interpretation of the hydrothermal evolution of the Spanish Central System. Drs Spiro and Darbyshire (NIGL, Keyworth, UK) and Reyes (Estación Experimental del Zaid ín, Granada, Spain) are also acknowledged for their help in the isotopic analysis. The mass spectrometry analysis of fluid inclusions was performed in the British Geological Survey (Keyworth, UK) with the help of Dr T.J. Shepherd while the RAMAN analyses were done by Dr E. Quilez at CREGU (France). Drs A. Canals and D. Banks are thanked for their stimulating comments about the evolution of these hydrothermal systems. Thanks are extended to Drs Simon M.F. Sheppard and another anonymous reviewer for their comments on the original manuscript and to Dr B. Lehmann for the editing. Dr David Banks is thanked for his careful reading and improvement of the English.

\section{References}

Antona JF, Fallick AE, García Sanchez A (1994) Fluid inclusion and stable isotope studies of gold-tungsten bearing hydrothermal deposits, Saucelle-Barrnecopardo area, Spain. Eur J Minera 16: 819835

Aparicio A, Borschevski YA, Borisova SL, Novitski I, Garcia Cacho A (1986) Relaciones isotópicas de ${ }^{18}$ en el ambiente plutónico metamórfico del Sistema Cen Minero 97-5: 672681

Bonhomme MG, Baubron JC, Jebrak M (1987) Mineralogie, geochimie, terres rares et age $\mathrm{K}-\mathrm{Ar}$ des argiles associees aux mineralisations filoniennes. Chem Geol 65: 321339

Borthwick J, Harmon $\mathrm{R}$ (1982) A note regarding $\mathrm{ClF}_{3}$ as an alternative to $\mathrm{BrF}_{5}$ for oxygen isotope analysis. Geochim Cosmochim Acta 46: 16651668

Bril H, Bonhomme MG, Marcoux E, Baubron JC (1991) Ages K/ $\mathrm{Ar}$ des mineralisations de Brioude-Massiac (W-Au-As-Sb; $\mathrm{Pb}$ $\mathrm{Zn})$, Pontgibaud $(\mathrm{Pb}-\mathrm{Ag} ; \mathrm{Sn})$, et Labessette (As- $\mathrm{Pb}-\mathrm{Sb}-\mathrm{Au})$ : place de Çes dis dans l'evolution geotectonique du Massif central franais. Miner Deposita 26: 189198

Caballero J M (1993) Las episienitas de la Sierra de Guadarrama: un caso singular de alteración hidrotermal de edad posthercínica. Doctoral Thesis, Universidad Complutense Madrid

Caballero JM, Casquet C, Galindo C, González Casado JM, Pankhurst R, Tornos F (1993) Geocronología por el método $\mathrm{Rb}-\mathrm{Sr}$ de las episienitas de la Sierra de Guadarrama, SCE, Espa ña. Geogaceta 13: 1618

Caballero JM, Casquet C, Galindo C, González Casado JM, Snelling N, Tornos F (1992) Dating of hydrothermal events in the Sierra del Guadarrama, Spanish Central System. Geogaceta 11: 1821

Campbell A, Rye D, Petersen U (1984) A hydrogen and isotope study of the San Cristobal Mine, Perú: implications of the role of water to rock ratio for the genesis of wolframite deposits. Econ Geo1 79: 18181832
Canals A, Cardellach E (1992) Strontium and sulphur isotope geochemistry of low-temperature $\mathrm{Ba}-\mathrm{F}$ veins of the Catalonian Coastal Ranges (NE Spain): a fluid mixing model and age constraints. Chem Geol 104: 269280

Capote R, Carbó A (1983) La evolución tectónica de los dominios de plataforma e intermedios. In: Comba J (ed) Geologia de Espa ña, vol II. IGME, Madrid, pp 3746

Casillas R, Brändle JL, Huertas MJ, Peinado M, Pérez Soba C, Villaseca C (1991) Contenidos y variación de las tierras raras en los granitoides tardihercínicos de la Sierra de Guadarrama (SCE). Bol Soc Esp. Mineral 14: 251272

Casquet C, Tornos F (1984) El skarn de W-Sn del Carro del Diablo (Sistema Central Español). Bol Geol Minero 95-1: 5879

Casquet C, Fúster J M, González Casado J M, Peinado M, Villaseca C (1988) Extensional tectonics and granite emplacement in the Spanish Central System. A discussion. In: Banda E, MendesVictor LA (eds) V EGT Workshop: the Iberian peninsula European Science Foundation, p 65

Casquet C, Galindo C, González Casado J M, Alonso A, Mas R, Rodas M, García E, Barrenechea JF (1992a) El metamorfismo en la cuenca de los Cameros: Geocronología e implicaciones tectónicas. Geogaceta 11: 22 25

Casquet C, Tornos F, Caballero J M, Galindo C (1992b) A revised model for the formation of dequartzified and alkalinized granites (episyenites). In: Kharaka Y, Maest A (eds) Proceedings $7^{\text {th }}$ International Symposium on Water Rock Interaction. Balkema, Rotterdam, pp 14811484

Chamberlain CP, Zeitler K, Barnett DE, Winslow D, Poulson SR, Leahy T, Hammer JE (1995) Active hydrothermal systems during the recent uplift of Nanga Parbat, Pakistan Himalaya. J Geophys Res 100-B1: 439453

Chen Y, Zentilli MA, Clark AH, Farrar E, Grist AM, WillisRichard J (1996) Geochronological evidence for post-Variscan cooling and uplift of the Cammenellis granite, SW England. J Geol Soc 153: 191195

Clayton RN, Mayeda T K (1963) The use of bromine penta fluoride in the extraction of oxygen from oxides an silicates for isotopic analysis. Geochim Cosmochim Acta 27: 4352

Cole DR (1992) Possible evidence for fluid-rock oxygen isotope disequilibrium in hydrothermal systems. In: KharakaY, Maest A (eds) Proceedings $7^{\text {th }}$ International Symposium on Water Rock Interactions. Balkema, Rotterdam, pp 995 998

Cole DR (1994) Oxygen isotope exchange rates in mineral fluid systems: correlations and predictions. Mineral Mag 58a: 189 190

Concha A, Oyarzun R, Lunar R, Sierra J, Doblas M, Lillo J (1992). The Hiendelaencina epithermal silver-base metal district, central Spain: tectonic and mineralizing processes. Miner Deposita 27-2: 8389

Conrad ME, 'Neil JR, Petersen U (1995) The relation between widespread ${ }^{18}$ depletion patterns and precious metal mineralization in the Tayoltita Mine, Durango, Mexico. Econ Geol 90-2: 322342

Craw D, Chamberlain CP (1996) Meteoric incursion and oxygen fronts in the Dalradian metamorphic belt, SW Scotland: a new hypothesis for regional gold mobility. Miner Deposita 31-5: 365373

Criss RE, Taylor HP (1986) Meteoric-hydrothermal systems. In: Valley JW, Taylor HP, 'Neil JR (eds) Stable isotopes in high temperature geological processes. Rev Mineral 16: 373424

Delgado J (1993) Caracterización mineralógica, fisicoquímica y geoquímica de los skarns del contacto norte del batolito de La Maladeta (Vall d'Aran, Lleida). Doctoral Thesis, Univ Barcelona

Dill H, Nielsen H (1987) Geochemical and geologic constraints of the unconformity-related vein baryte deposits of cental Europe. J Geol Soc 144: 97105

Doblas M (1987) Tardy-hercynian extensional and transcurrent tectonics in central Iberia. Proceedings Conference on Deformation and Plate Tectonics. Oviedo, Spain, p 29 
Doblas M, Oyarzun R, Sopeña A, López Ruiz J, Capote R, Hernández Enrile JL, Hoyos M, Lunar R (1994) Variscan-late Variscan-early Alpine progressive extensional collapse of cen tral Spain. Geodinamica Acta 7-1: 114

Einaudi MT, Meinert LD, Newberry RJ (1981) Skarn deposits. In Skinner B (ed) Econ Geol 75 Anniversary Volume, pp 317391

Fehn U (1985): Postmagmatic convection related to HHP in granites of SW England. High heat production granites. Inst Mining Metallurgy, London, pp 99112

Friedman I, 'Neil JR (1977) Data of geochemistry. Compilation of stable isotope fractionation factors of geochemical interest. Geological Survey Professional Paper 440-KK

Fritz P, Frape SK (1982): Saline groundwaters in the Canadian shield. A first overview. Chem Geol 36: 179190

Galindo C, Huertas MJ, Casquet C (1994a) Cronologia Rb-Sr y KAr de diques de la Sierra de Guadarrama (Sistema Central Español). Geogaceta 16: 2326

Galindo C, Tornos F, Darbyshire DPF, Casquet C (1994b) The age and origin of the barite-fluorite $(\mathrm{Pb}-\mathrm{Zn})$ veins of the Sierra del Guadarrama (Spanish Central System): a radiogenic (Nd, Sr) and stable isotope study. Chem Geol 112: 351364

Giggenbach WF (1995) Composition of magmatic components in hydrothermal fluids. In: Thompson JFH (ed) Magmas, fluids and ore deposits. Miner Assoc Can Short Course 23: 247261

Giletti BJ, Semet MP, Yund RA (1978) Studies in diffusion III -xygen in feldspars, an ion microprobe determination. Geochim Cosmochim Acta 42: 4557

Giletti BJ, Yund RA (1984) Oxygen diffusion in quartz. J Geophys Res 89: 40394046

Godfrey JA (1962) The deuterium content of hydrous minerals from the East Central Sierra Nevada and Yosemite National Park. Geochim Cosmochim Acta 26: 12151245

González Casado JM, Caballero JM, Casquet C, Galindo C, Tornos F (1996) The transition Hercynian-Alpine cycle in the Sierra del Guadarrama (Eastern Iberian Central System). Paleostress field and geotectonic interpretation. Tectonophysics 262: 213229

González Casado JM, Casquet C, Caballero JM, Galindo C, Quílez E, Tornos F (1993) Análisis de la fracturación asociada a las alteraciones de ipo greisen y episienita en la Sierra del Guadarrama. Geogaceta 13: 5356

Graham CM, Harmon RS, Sheppard SMF (1984) Experimental hydrogen isotope studies: hydrogen isotope exchange between amphibole and water. Am Mineral 69:128 138

Halliday AN, Mitchell JG (1984) K-Ar ages of clay-size concentrates from the mineralisation of the Pedroches batholith and evidence for Mesozoic hydrothermal activity associated with the break up of Pangea. Earth Planet Sci Lett 68: 229239

Hedenquist JW, Arribas A, Reynolds TJ (1998) Evolution of an intrusion centered hydrothermal system: far southeast Lepanto porphyry and epithermal $\mathrm{Cu}-\mathrm{Au}$ deposits. Econ Geol 93-4: 373 404

Hoefs J, Emmermann R (1983) The oxygen isotope composition of Hercynian granites and pre-Hercynian gneisses from the Schwarzwald, SW Germany. Contrib Mineral Petrol 834: 320 329

Ibarrola E, Villaseca C, Vilette Y, Fúster J M, Navidad M., Peinado $\mathbf{M}$, Casquet C (1988) Dating of Hercynian granites in the Sierra de Guadarrama (Spanish Central System). In: Geología de los granitoides y rocas asociadas del MacizoHespérico, ed Rueda, Madrid, pp 377383

Jackson NJ, Halliday AN, Sheppard SMF, Mitchell JG (1982) Hydrothermal activity in the St Just Mining District, Cornwall, England. MAWAM 6:137 179

Jackson NJ, Willis-Richards J, Manning DA, Sams MS (1989) Evolution of the Cornubian ore field, SW England: Part I Mineral deposits and ore forming processes. Econ Geol 84-5: 11011133

Jenkin GRT, Craw D, Fallick AE (1994) Stable isotopic and fluid inclusion evidence for meteoric fluid peneration into an active mountain belt; Alpine Schist, New Zealand. J Metamorph Geol 12: 429444 ohnson CA, Cardellach E, Tritlla J, Hanan B B (1996) Cierco Pb$\mathrm{Zn}-\mathrm{Ag}$ vein deposits: isotopic and fluid inclusion evidence for formation during the Mesozoic extension in the Pyrenees of Spain. Econ Geol 91 93: 497506

Kelly WC, Rye RO (1979) Geologic, fluid inclusion and stable isotope studies of the tin-tungsten deposits of Panasqueira, Portugal. Econ Geol 74: 1721 1819

Kerry WC, Wagner GA (1977) Paleothermometry by combined application of fluid inclusion and fission track methods. Neues Jahrb. Mineralogie Montash 1: 115

Krahn L, Baumann A (1996) Lead isotope systematics of epigenetic lead-rinc mineralization in the western part of the Rheinisches Schiefergebirge, Germany. Miner Deposita 31-3: 225237

Lillo J, Oyarzun R, Lunar R, Doblas M, González A, Mayor N (1992) Geological and metallogenic aspects of late Variscan Ba(F)-(base-metal) vein deposits of Spanish Central System. Trans Inst Min Metall 101: b24 b31

Locutura J, Tornos F (1985) Consideraciones sobre la metalogenia del sector medio del Sistema Central Espa ñol. Rev Real Acad Cien Físicas, Exactas Naturales 59: 589623

Longinelli A (1968) Oxygen isotope composition of sulfate ions in seawater and saline lakes. Earth Planet Sci 156: 5659

Mangas J, Arribas A (1987) Fluid inclusion study in different types of tin deposits associated with the Hercynian granites of western Spain. Chem Geol 61: 193208

Mangas J, Pérez Torrado FJ (1995) Fluid inclusion and stable isotope studies in Sn-W deposits of western Spain. In: Pasava J, Kribek B, Zak K (eds) Mineral deposits: from their origin to environmental impacts. Balkema, Rotterdam, pp 473476

Martín Crespo T, López JA, Banks D, Vindel E (1997) Composición y origen de los filones de cuarzo estéril (Sistema Cen wal Español). Bol Soc Esp. Mineral 20-A: 5354

Martinez Frías J (1992) The Hiendelaencina mining district (Guadalajara, Spain). Miner Deposita 27-3: 206212

Mavrovenges JA, Bodnar RJ (1994) Hydrogen movement into and out of fluid inclusions in quartz: experimental evidence and geological implications. Geochim Cosmochim Acta 58 141148

Mayor N, Lunar R, Oyarzun R (1989) Fenómenos de alteraciónmineralización en los yacimientos de Ba-F- $(\mathrm{Pb}-\mathrm{Zn}-\mathrm{Cu}-(\mathrm{Ag})$ de la Sierra de Guadarrama. Bol Soc Esp. Mineral 12: 273282

Moore JN, Gunderson RP (1995) Fluid inclusion and isotopic systematics of an evolving magmatic-hydrothermal water Geochim Cosmochim Acta 59-19: 38873907

Mullis J, Dubessy J, Poty B, 'Neil J (1994) Fluid regimes during late stages of a continental collision: physical, chemical and stable isotope measurements of fluid inclusions in fissure quartz from a geowansverse through the central Alps, Switzerland Geochim Cosmochim Acta 58-10: 22392267

Mutti M, Weissert H (1996) Triassic monsoonal climate and its signature in Ladinian Carnian carbonate platforms (southern Alps, Italy). J Sediment Res (Sect B) 65: 357367

Nesbitt BE, Murowchick JB, Muehlenbachs K (1986) Dual origins of lode gold deposits in the Canadian Cordillera. Geology 14: 506509

Noronha F (1984) Caracteristiques physico-chimiques des fluides associes a la genese du gisement de tungstene de Borralha (Nord Portugal). Bull Mineral 107: 273284

-'Neil JR, Taylor HP (1967) The oxygen isotope and cation exchange chemistry of feldspars. Am Mineral 52: 14141437

Parrish JT, Ziegler AM, Scotese CR (1982) Rainfall patterns and the distribution of coals and evaporites in the Mesozoic and Cenozoic. Palaeogeogr Palaeoclimatol Palaeoecol 40: 67 101

Pérez Soba C (1991) Petrología y geoquímica del macizo granítico de La Pedriza. Doctoral Thesis, Univ Complutense Madrid

Quílez E (1994) Mineralizaciones filonianas de wolframio de la Sierra de Guadarrama: modelo y caracterización del proceso hidrotermal. Doctroal Thesis Univ Complutense Madrid

Quílez E, Sierra J, Vindel E (1990) A fluid inclusion study and genetic model of wolframite bearing quartz veins, Garganta de los Montes, Spanish Central System. Mineral Mag 54: 267278 
Ramboz C, Schnapper D, Debussy J (1985) The P-V-TX-fo ${ }_{2}$ evolution of $\mathrm{H}_{2}-\mathrm{CO}_{2}-\mathrm{CH}_{4}$ bearing fluid in a wolframite vein: reconstruction from fluid inclusion in studies. Geochim Cosmochim Acta 49: 205219

Recio C, Fallick AE, Ugidos JM (1991) Sulphur isotope systematics of granitoids and associated rocks from the Avila- La Alberca área (Western Sistema Central, Spain). Rev Soc Geol Espa ña 4: 371381

Recio C, Fallick AE, Ugidos JM (1992) A stable isotopic $\left(\delta^{18} \boldsymbol{\theta}\right.$, $\delta$ D) study of late Hercynian granites and their host-rocks in the Central Iberian Massif (Spain). Trans R Soc Edin Earth Sci 83 : 247257

Reyes E, Caballero C, Delgado A, Cortecci G (1995) Alteraciones hidrotermales y meteóricas del macizo de El Berrocal: estudio isotópico. II Jornadas I+ D en la gestión de residuos radiactivos. ENRESA II: 4353

Reyes E, Pérez L, Delgado A, Cortecci G, Nuñez R, Pelayo M, Cózar JS (1998) Carbonation processes at the El Berrocal natural analogue granitic system (Spain): Inferences from mineralogical and stable isotope studies. Chem Geol 150: 293315

Robinson BW, Kusakabe M (1975): Quantitative preparation of sulphur dioxide for ${ }^{34} \mathrm{~S} /{ }^{32} \mathrm{~S}$ analyses from sulphides by combustion with cuprous oxide. Anal Chem 47: 11791181

Roedder E (1984) Fluid inclusions. Rev Mineral 12: 644 pp

Rozanski K, Araguás L, Gonfiantini R (1993) Isotopic patterns in modern global precipitation. In: Climatic change in continental isotopic records (ed AGU). Geophys Monogr 78: 136

Sheppard SMF (1986a) Igneous rocks III. Isotopic case studies of ma gmatism in Asia, Euroasia and oceanic islands. Rev Mineral 16: 319371

Sheppard SMF (1986b) Characterization and isotopic variations in natural waters. In: Valley JW, Taylor HP, 'Neil JR (eds) Stable isotopes in high temperature geological processes. Rev Mineral 16: 165184

Sheppard SMF, Gilg HA (1996) Stable isotope geochemistry of clay minerals. Clay Minerals 31: 124

Shinohara H, Kazahaya K (1995) Degassing processes related to magma-chamber crystallization. In: Thompson JFH (ed) Magmas, fluids and ore deposits. Miner Assoc Can Short Course 23: 2570

Smith M, Banks DA, Yardley BW, Boyce A (1996) Fluid inclusion and stable isotope constraints on the genesis of the Cligga Head Sn-W deposit, SW England. Eur J Mineral 8: 961974

Suzuoki T, Epstein S (1976) Hydrogen isotope fractionation between $\mathbf{O H}$-bearing minerals and water. Geochim Cosmochim Acta 40: 2291240

Taylor HP (1979) Oxygen and hydrogen isotope relationship in hydrothermal mineral deposits. In: Barnes HL (ed.) Geochemistry of hydrothermal ore deposits, 2nd edn. Wiley, New York, pp 236227

Taylor HP, Sheppard SMF (1986) Igneous rocks: I. Processes of isotopic fractionation and isotope systematics. In: Valley JW, Taylor HP, 'Neil JR (eds) Stable isotopes in high temperature geological processes. Rev Mineral 16: 227272

Thadeu D (1982) Gites filoniens a $\mathrm{Pb}, \mathrm{Zn}$ et Ba posthercyniens au Portugal. Bull. BRGM II-2: 207209

Titley AR, Beane RE (1981) Porphyry copper deposits: Part I: Geologic setting, petrology and tectogenesis. Econ Geol 75 : 214234

Tornos F (1990) Los skarns y mineralizaciones asociadas del Sistema Central Espa ñol. Modelo de caracterización petrológica, geoquimica y metalogénica. Doctoral Thesis, Universidad Complutense de Madrid
Tornos F, Casquet C, Locutura J, Collado R (1991) Fluid inclusion and geochemical evidence for fluid mixing in the genesis of $\mathrm{Ba}-\mathrm{F}$ $(\mathrm{Pb}-\mathrm{Zn})$ lodes of the Spanish Central System. Mineralogical Magazine 55: 225234

Tornos F, Casquet C, Caballero JM (1993a) La alteración bidrotermal asociada al plutón epizonal de Navalcubilla, Sierra de Guadarrama (Sistema Cen ral Español). Rev Sociedad Geológica Espa ña 6(1 2): 6784

Tornos F, Casquet C, González Casado J M (1993b) Comments on the paper by A. Concha, R. Oyarzun, R. Lunar, J. Sierra, M. Doblas and J. Lillo: The Hiendelaencina epithermal silver-base metal district, central Spain: tectonic and mineralizing processes. Miner Deposita 28-3: 217218

Tornos F, Casquet C, Galindo C, Caballero J M (1995) El skarn de Arroyo Zancado: un caso peculiar de skarn de tipo $\mathrm{Ca}-(\mathrm{Fe})$ en la Sierra de Guadarrama (Sistema Central Español). Bol Soc Esp. Mineral 18: 99110

Tornos F, Delgado A, Casquet C, Galindo C, Reyes E (1996) La evolución isotópica de los fluidos ligados a los sistemas hidrotermales tardi y postvariscos del Sistema Cen Español. Geogaceta 20 7: 15011503

Tornos F, Chiaradia M, Fontboté L (1998) La geoquímica isotópica del plomo en las mineralizaciones de la Zona de Ossa Morena (ZⓂ): Implicaciones metalogen éticas y geotectónicas. Bol. Soc. Esp. Mineralogia 21-A: 206207

Turpin L, Leroy J L, Sheppard S MF (1990) Isotopic systematics ( $\mathrm{H}, \mathrm{C}, \mathrm{Sr}, \mathrm{Nd}$ ) of superimposed barren and U-bearing hydrothermal systems in an Hercynian granite, Massif Central, France. Chem Geol 88: 8598

Vennemann T, Smith H (1990) The rate and temperature of reac tion of $\mathrm{ClF}_{3}$ with silicate minerals, and their relevance to oxygen isotope analysis. Chem Geol 86: 8388

Vialette Y, Casquet C, Fúster JM, Ibarrola E, Navidad M, Peinado M, Villaseca C (1987) Geochronological study of orthogneisses from the Sierra de Guadarrama (Spanish Cen ral System). Neues Jahrb Miner Monatsh 10: 465 479

Villaseca C, Barbero L, Huertas MJ, Andonaegui P, Bellido F (1993) A cross section through Hercynian granites of Cen ral Iberian Zone. Excursion Guide. Servicio Publicaciones CSIC, Madrid

Vindel E (1980) Estudio mineralógico y metalogénico de las mineralizaciones de la Sierra de Guadarrama. Doctoral Thesis Universidad Complutense Madrid

Vindel E, López J, Boiron MC, Cathelineau M, Prieto AC (1995) $\mathrm{P}-\mathrm{V}-\mathrm{T}-\mathrm{X}-\mathrm{f} \mathrm{O}_{2}$ evolution from wolframite to sulphide depositional stages in intragranitic W-veins. An example from the Spanish Central System. Eur J Mineral 7: 675688

Virgili C, Sopeña A, Ramos A, Arche A, Hernando S (1983) El relleno posthercínico y comienzo de la sedimentación mesozoica. In: Comba JA (ed) Geología de España, vol II. IGME, pp 2536

Zheng YF (1991) Calculation of oxygen isotope fractionation in metal oxides. Geochim Cosmochim Acta 55: 22992307

Zheng YF (1992) xygen isotope fractionation in wolframite. Eur J Mineral 4: 13311335

Zheng YF (1993) Calculation of oxygen isotope fractionation in anhydrous silicate minerals. Geochim Cosmochim Acta 57: 10791091

Ziegler AM, Scotese CR, Barrett SF (1983) Mesozoic and Cenozoic paleogeographic maps. In: Broesche P, Sündermann J (eds) Tidal friction and the Earth's rotation II. Springer, Berlin Heidelberg New York, pp 240252 